\title{
A revision of Ampbimenes (Coleoptera: Carabidae: Lebiini)
}

\section{Ревизия рода Amphimenes (Coleoptera: Carabidae: Lebiini)}

\author{
D.N. Fedorenko \\ A.H. Федоренко
}

\begin{abstract}
A.N. Severtsov Institute of ecology and evolution, Leninsky pr. 33, Moscow 119071, Russia. E-mail: dmitri-fedorenko@yandex.ru Институт проблем экологии и эволюции им. А.Н. Северцова, Российская Академия Наук, Ленинский пр-т 33, Москва 119071, Россия.
\end{abstract}

KEY WORDS: Coleoptera, Carabidae, Amblops, Amphimenes, new subgenus, species, new synonym, new record, Vietnam, Oriental region.

КЛЮЧЕВЫЕ СЛОВА: Coleoptera, Carabidae, Amblops, Amphimenes, новый подрод, новый вид, новый синоним, новая находка, Вьетнам, Ориентальная область.

ABSTRACT. The polytypic genus Amphimenes Bates, 1873 is subdivided into three subgenera, including Amphinemes subg.n. and Amblops Andrewes, 1931, stat.n., the latter being formerly considered as a separate monobasic genus. Ten new species, Amphimenes acutipennis sp.n., A. basipunctatus sp.n., A. bicoloripes sp.n., A. femoralis sp.n., A. konplongensis sp.n., A. marginicollis sp.n., A. ruficollis sp.n., A. similis sp.n., A. subcostatus sp.n., and $A$. tonkinensis sp.n., all from Vietnam, are described. A refined key to species is provided and new records are briefly discussed. New synonymy is established: A. ryukyuensis Habu, $1969=$ A. carinacaulis Hunting et Yang, 2019, syn.n.

РЕЗЮМЕ. Политипический род Amphimenes Bates, 1873 подразделён на 3 подрода: номинативный, Amphinemes subg.n. и ранее рассматривавшийся в качестве самостоятельного рода Amblops Andrewes, 1931, stat.n. Из Вьетнама описано 10 новых видов: Amphimenes acutipennis sp.n., A. basipunctatus sp.n., A. bicoloripes sp.n., A. femoralis sp.n., A. konplongensis sp.n., A. marginicollis sp.n., A. ruficollis sp.n., A. similis sp.n., и $A$. subcostatus sp.n. и A. tonkinensis sp.n. Переработана таблица для определения видов Amphimenes. Кратко обсуждены новые находки некоторых видов. Установлена синонимия: A. ryukyuensis Habu, $1969=$ A. carinacaulis Hunting et Yang, 2019, syn.n.

\section{Introduction}

The Oriental genus Amphimenes Bates, 1873 belongs to the subtribe Pericalina, Lebiini. The members of the subtribe, including many species of the genus, are mostly small to medium-sized, nocturnal, arboricolous carabids that prefer to live on dead, standing to fallen, trees. Most of these species run on tree trunks and use exfoliated bark of dead trees or bark scales of living trees as covers to rest. They fly well to seek for these habitats and their ranges are usually large following the macropterous condition. On the other hand, there are many species within the genus that have lost capacity for flight in course of evolution from arboricoles into soildwellers; these inhabit the underside of smaller tree trunks, broken tree branches and bark fragments on the ground, and sometimes penetrate into strongly decomposed rotten logs. Accordingly their distribution patterns have become restricted for which reason many apterous species of Amphimenes have hitherto been known from a few localities in montane areas.

The genus was re-described and reviewed recently [Fedorenko, 2010], with several new species described afterwards [Fedorenko, 2014; Hunting, Yang, 2019]. In this paper we contribute next eleven species, among them new ten, to Amphimenes and subdivide the genus into three subgenera.

The bulk of material was collected during expeditions and field trips to montane regions in Vietnam, sponsored by the Russia-Vietnam Tropical Centre. Acronyms used are: BMNH - Natural History Museum, London, London; MPSU - Moscow Pedagogical State University; SIEE - the author's reference collection at A.N. Severtsov Institute of Ecology \& Evolution, Russian Academy of Sciences, Moscow; ZISP - Zoological Institute, Russian Academy of Sciences, St. Petersburg; ZMMU Zoological Museum of the Moscow State University.

The following parameters were analyzed: BL, maximum body length measured between apices of closed mandibles and apex of elytra; Dn - distance between base of elytron and discal pore $\mathbf{n}=1,2$, and 3; EL maximum length of elytron, measured between apex and highest point of base; ES3L — length of metepisternum along outer margin; ES3W - width of metepisternum at anterior margin; EW - maximum width of elytra; HW — width of head across eyes; PL — length of pronotum along median line; $\mathrm{PW}$ - maximum width

How to cite this article: Fedorenko D.N. 2019. A revision of Amphimenes (Coleoptera: Carabidae: Lebiini) // Russian Entomol. J. Vol.28. No.3. P.233-250. doi: 10.15298/rusentj.28.3.02 
of pronotum; PA - width of pronotum between apical angles; PB - width of pronotum between basal angles.

Measurements were taken using an eyepiece micrometer, to two decimal places. The number of specimens measured (n) is only given for the first ratio in the description. All labels are printed, unless marked '[hw]' (= handwritten). Data on labels of type specimens are in quotes. Provinces of Vietnam and Thailand are in italics.

\section{Results}

\section{Amphimenes Bates, 1873}

Bates, 1873: 322; Jedlička, 1963: 366; Habu, 1964: 472; 1967 : 113; 1982: 90; Fedorenko, 2010: 18; 2014: 310.

Type-species: Amphimenes piceolus Bates, 1873 (by monotypy) REDESCRIPTION. Unnecessary here, except for some features not mentioned before, including the following leg characters: (1) profemur with a ventrobasal tubercle, (2) mesotrochanter ventrally (posteriorly) with a very fine longitudinal ridge, (3) mesotibia minutely tuberculate along apical $1 / 2-2 / 3$ inner margin; and (4) a pointed tubercle at middle of its wider, mesal, part of the metacoxa. For details see below.

COMMENTS. Fedorenko [2010] arranged all species into five species groups: the rugulipennis-group, the piceolus-group, the medius-group, the rufipes-group, and the planicollis-group; the former two groups are arboricolous and the remainder include soil-dwelling species. The planicollisgroup was then [Fedorenko, 2014] subdivided into the nominal subgroup and the brunneus-subgroup, with the rufipesgroup being considered as a subgroup of the planicollisgroup. All these groupings are treated as separate species groups below, except that the subgenus Amphinemes subg.n. is introduced for the rugulipennis-group.

Out of the generic characters mentioned above, the profemoral tubercle is more or less distinct in A. medius (the medius-group), A. femoralis sp.n. (the brunneus-group), three of four species of Amphinemes subg.n., and A. (Amblops) marginicollis sp.n.

The mesotrochanteral ridge adjoins or almost adjoins apical trochanteral seta in almost all Amphimenes species for which males are known. It is longest yet slightly tuberculate apically in A. reflexicollis while more or less shortened and/or modified into a minute preapical tubercle to denticle in most other congeners, being combined with vestigial or totally reduced seta in all species but two. These have no ridge/ tubercle, but the seta is well-developed (A. planipennis) or barely shortened (A.femoralis $\mathbf{s p . n . ) . ~ T h i s ~ m a y ~ s u g g e s t ~ t h a t ~ t h e ~}$ seta was gradually reduced as the ridge developed in course of morphological evolution. Accordingly, the pattern observed in A. planipennis and A. femoralis sp.n. could be recognized as plesiomorphous for the genus, and a minute tubercle or nearly indistinct ridge - since the two characters are combined with vestigial or missing seta - as secondary reductions.

The mesotibial tubercles are minute and range between species in number, from mostly four (A. bicoloripes sp.n., $A$. femoralis sp.n., A. konplongensis sp.n., A. marginicollis sp.n., A. medius, A. micros, A. planicollis, A. reflexicollis) or five (A. acutipennis sp.n., A. basipunctatus sp.n., A. planipennis, $A$. similis sp.n.) through three (A. gracilis, A. maculatus, A. ruficollis sp.n.) to one (A. piceus, A. subcostatus sp.n.) or none (A. giganteus).

Most species have the umbilical seta series (USS) consisting of 15 setae/setigerous pores (US) that runs on elytral interval 9; these are arranged into two groups, anterior, or posthumeral (nine setae included), and posterior, or postmedian (six setae). The USS groundplan seems to include these groups more or less widely separated, with US6, US8 and US11 approximating to or touching stria 9 (the piceolusgroup). The members of the subgenus Amblops are similar, except for setigerous pores being large, barely smaller than the width of interval 9. The subgenus Amphinemes subg.n. is farther advanced due to the anterior and posterior pore groups more widely gaped in its members, with US6, US8 and US11 adjoining stria 9 .

In most soil-dwelling species, USS apparently evolved toward a despecialized condition defined by US becoming continuous or almost so, less oscillating across interval 9, and additional US appeared. Most of these species have retained 15 US, whereas the rest have US increased to either 17-18 ( $A$. basipunctatus sp.n., A. reflexicollis) or 16-19 (A. konplongensis sp.n.), or 20-21 (A. acutipennis sp.n.) in number. But $A$. giganteus which is closely related to A. acutipennis sp.n. has retained nearly groundplan USS pattern.

KEY TO SUBGENERA, SPECIES GROUPS AND SPECIES OF AMPHIMENES

1(10) Elytral striae punctate, intervals smooth. Eyes large and nearly hemispherical, genae indistinct or almost so. Pronotum transverse, PW/PL 1.48-1.67, with reflexed lateral margin pale. Elytral microsculpture consisting of large transverse meshes

2 Subgenus Amblops Andrewes, 1931

2(9) Elytral interval 3 trisetose, with setigerous pores d1 and d2 more or less foveate; elytral striae deep and distinctly punctate. Body dorsum, including clypeus and labrum, black, with lateral margins of both pronotum and elytra pale ................................................... the piceus-group

3(6) Body small, $\mathrm{BL}<5.5 \mathrm{~mm}$; pronotum small, only a fourth wider than head and about half wider than long, with reflexed lateral margin narrow. Antennae infuscated, with basal four segments pale.

4(5) Elytral striae rather shallow, intervals flat. Elytra flattened and shorter, EL/EW 1.40-1.47, with microsculpture strongly transverse. BL 5.5-6 mm. - Northern India 2.1. A. (Amblops) piceus Andrewes, 1931

5(4) Elytral striae very deep, intervals convex. Elytra convex, half longer than wide, with microsculpture slightly less transverse. Body slightly smaller, BL $5.2 \mathrm{~mm}$. - Laos, southern Vietnam .... 2.2. A. (Amblops) subcostatus sp.n.

6(3) Body larger, $\mathrm{BL}>5.7 \mathrm{~mm}$; pronotum large, $1 / 2-2 / 5$ wider than head and about three fifths wider than long, with lateral margin widely explanate. Antennae entirely pale.

7(8) Pronotum with sides straight or subconvex behind middle, basal angles obtuse and widely rounded apically, base a third wider than apex. Aedeagus sclerotized except apical orifice. BL 5.8-6.8 mm. - China (Taiwan) ....... ..... A. (Amblops) absensacidus Hunting et Yang, 2019

8(7) Pronotum larger, sides distinctly sinuate before slightly obtuse and blunt basal angles, base nearly half wider than apex. Aedeagus membranous both apically and dorsomedially. BL 5.9-6.4 mm. - Northern Vietnam 2.3. A. (Amblops) marginicollis sp.n.

9(2) Elytra with two non-foveate setigerous pores in interval $3, \mathrm{~d} 2$ and $\mathrm{d} 3$; striae subpunctate and rather shallow; intervals flat. Clypeus, labrum and pronotum reddishyellow, elytra with two transverse bands, subhumeral and preapical, the former interrupted at suture while the latter entire. Body very small, BL $4.5 \mathrm{~mm}$. Eyes slightly flattened ................................................................. 
10(1) Elytral striae impunctate, intervals cross-striated. Elytral microsculpture consisting of small (=dense) transversemeshes to dense transverse lines, rarely isodiametric. Labrum and clypeus entirely or partly pale except in one species.

11(18) Elytra with a trimaculate pale pattern including subhumeral spots and common macula formed by preapical spots contiguous or fused along suture (Fig. 5), lateral margins of both pronotum and elytra, legs and antennae pale. Elytral intervals densely cross-striated; interval 3 with three setae, including d1 close to base (D1/EL ca 0.15 ) and $\mathrm{d} 2$ at middle (D2/EL 0.43-0.53). Body macropterous and robust, with eyes large and rather prominent, pronotum transverse, PW/PL 1.49-1.63, and elytra more or less square ................. 1. Amphinemes subg.n.

12(13) Elytral microsculpture consisting of fine and very dense transverse lines not forming distinct meshes. Elytral spots smaller, subhumeral on intervals 3-8 just behind humerus, not posteriorly surpassing midway between setae $\mathrm{d} 1$ and $\mathrm{d} 2$; preapical spot not anteriorly surpassing midway between $\mathrm{d} 2$ and $\mathrm{d} 3$. Profemur with small and blunt ventrobasal tubercle in male. Larger, BL 6.3-7.7 mm. - Myanmar, Thailand to Vietnam (Dong Nai, Binh Phuoc, Dak Lak, Nghe An)....

...... 1.1. A. (Amphinemes) rugulipennis (Bates, 1892)

13(12) Elytral microsculpture consisting of very transverse yet distinct meshes; elytral spots larger, subhumeral on intervals 3 to 7 distinctly behind humerus and posteriorly surpassing midway between setae $\mathrm{d} 1$ and $\mathrm{d} 2$; preapical spot anteriorly surpassing midway between $\mathrm{d} 2$ and $\mathrm{d} 3$. Profemur without or with a ventrobasal tubercle in male. Body generally smaller, BL 5.3-7.2 mm.

14(15) Smaller, BL 5.3-5.7 mm. Anterior elytral spot reaching $\mathrm{d} 2$ or nearly so. Clypeus and usually also labrum infuscated. Elytra shorter, EL/EW 1.32-1.42 (mean 1.35). Pronotum convex on disc, with explanate lateral margins moderately wide. Head and pronotum with very coarse, granulate, microsculpture. Profemur with a vestigial ventrobasal tubercle in male. - Thailand (Mae Hong Son), Vietnam (Dong Nai, Binh Phuoc), China (Hong-Kong) .

....... 1.2. A. (Amphinemes) maculatus Fedorenko, 2010

15(14) Larger, BL 5.9-7.4 mm. Anterior elytral spot extended apicad to about $2 / 3$ distance between $\mathrm{d} 1$ and $\mathrm{d} 2$. Labrum and greater part of clypeus pale. Elytra longer, EL/EW 1.42-1.50 (mean 1.45). Pronotum rather flat, with explanate lateral margins wider. Head and pronotum with microsculpture coarse yet more superficial, isodiametric rather than granulate.

16(17) Body more contrastingly bicoloured following black or brown black ground-colour; preapical elytral macula slightly constricted at suture. Profemur with a conspicuous pointed tubercle in male. - Northern Vietnam (Hai Phong)..... A. (Amphinemes) guttatus Fedorenko, 2014

17(16) Body generally paler, head and pronotum dirty red to dark brown red, elytra black brown, somewhat reddish, more so behind middle; preapical macula mostly deeply excavate on intervals $1-2$ at least anteriorly. Profemur without tubercle in male. - Central Vietnam ........................ 1.3. A. (Amphinemes) similis sp.n.

18(11) Dorsum unicolourous dark, sometimes with lateral margins of both pronotum and elytra paler; body appendages mostly darker than above. Elytral intervals densely cross-striated to (rarely) smooth; interval 3 either bisetose $(\mathrm{d} 1+\mathrm{d} 3$ or $\mathrm{d} 2+\mathrm{d} 3)$ or trisetose. Body macropterous to apterous, with eyes less convex to small and flat, pronotum less transverse, PW/PL 1.16-1.55, and elytra square to elliptic
19(42) Elytral discal setae either three, with d2 behind middle (D2/EL 0.58-0.76), or two, d1+d3. Elytral intervals crossstriated. Body macropterous or apterous.

20(33) Elytral interval 3 trisetose, d1 more than one fifth distant from base, D1/EL 0.22-0.33. Eyes fairly large to slightly flattened; posterior supra-ocular seta on a level with or just behind posterior margin of eye. - Mostly macropterous species of subcortical habits ...

the piceolus-group.

21(22) Brachypterous, eyes rather flat, elytra short and rounded on sides, EL/EW 1.21-1.38; metepisterna short, ES3L/ ES3W 1.07-1.11 [Habu, 1964], up to 1.42 [Hunting, Yang, 2019]. - China (Taiwan) A. (s.str.) asahinai Nakane, 1957

22(21) Macropterous; metepisternum longer; elytra mostly longer, with sides less strongly rounded.

23(24) Antennae short, not reaching elytral base. Elytra short, EL/EW 1.36, with intervals very finely and rather sparsely cross-striated. - China (Taiwan) ..... A. (s.str.) beichatiensis Hunting et Yang, 2019

24(23) Antennae and elytra longer, EL/EW 1.38-1.55 (1.451.48); elytral intervals rather densely cross-striated.

25(26) Elytral microsculpture consisting of transverse meshes. BL 5.8-7.0 mm. - Japan (Shikoku, Kyushu) ......... A. (s.str.) piceolus Bates, 1873

26(25) Elytral microsculpture consisting of very fine and dense transverse lines not forming distinct meshes.

27(30) Pronotum subcordate, with sides distinctly sinuate in front of basal angles.

28(29) Generally larger, BL 6.7-8.0 mm. Pronotum short and wide, PW/PL 1.36-1.55 (1.44). - Southern and Central Vietnam (From Lam Dong to at least Quang Binh) ...... 3.1. A. (s.str.) bidoupensis Fedorenko, 2010

29(28) Barely smaller in general, BL 6.2-7.6 mm. Pronotum barely narrower and longer, PW/PL 1.29-1.42 (1.36). Northern Vietnam (Thai Nguen, Cao Bang, Nghe An) ... .................... 3.2. A. (s.str.) gracilis Fedorenko, 2010

30(27) Sides of pronotum not or indistinctly sinuate in front of basal angles.

31(32) Body slender, with pronotum smaller and elytra longer: $\mathrm{PW} / \mathrm{HW} \leq 1.4, \mathrm{EW} / \mathrm{PW} \approx 1.6, \mathrm{EL} / \mathrm{EW} \approx 1.55$; reflexed lateral margin of pronotum narrower basally. BL 6.5-7.1 mm. - Japan (Ryukius)

3.4. A. (s.str.) ryukyuensis Habu, 1964 2(31) Body barely more robust, with pronotum larger and elytra shorter: $\mathrm{PW} / \mathrm{HW}>1.5, \mathrm{EW} / \mathrm{PW} \leq 1.55, \mathrm{EL} / \mathrm{EW} \leq 1.50$; reflexed lateral margin of pronotum wide to very wide basally. BL 6.2-7.6 mm. - Northern Vietnam (Lao Cai) 3.3. A. (s.str.) montanus Fedorenko, 2010

33(20) Elytral interval 3 with two, d1 $+\mathrm{d} 3$, or three setae, d1 being close to base, D1/EL 0.9-0.18. Eyes more or less flattened; posterior supra-ocular seta behind the level of posterior margin of eye. - Apterous soil-dwelling species

34(41) Elytra with three discal setae.

35(40) Body large or very large, BL 6.7-12 mm. Elytra with microsculpture distinctly transverse, mostly very so; seta $\mathrm{d} 2$ inserted behind middle, D2/EL 0.60-0.76. - Southern and Central Vietnam.

36(37) Elytra with posterolateral angles acute and sharp. Body very large, BL 10.1-11.9 mm. Elytra longer, with lateral margins wider and more reflexed; $\mathrm{d} 1$ distant far from base, D1/EL 0.16-0.18. Head shinier than pronotum owing to rather superficial isodiametric or granulate-aciculate microsculpture, respectively 3.5. A. (s.str.) acutipennis sp.n. 
37(36) Elytra with posterolateral angles obtuse or rounded. Body smaller. Elytra shorter, with lateral margins narrower and less strongly reflexed; d1 close to base, D1/EL $0.09-0.14$. Head and pronotum subequally dull from coarse microsculpture.

38(39) Elytra with posterolateral angles conspicuous, slightly obtuse and blunt; extreme apices separate. Body large, BL
8.5-10.6 mm. - Southern Vietnam (Lam Dong, Dak Lak) A. (s.str.) giganteus Fedorenko, 2010 39(38) Elytra with posterolateral angle very obtuse and rounded at apex; extreme apices contiguous. Body small, BL 6.7$8.1 \mathrm{~mm}$ 3.6. A. (s.str.) basipunctatus sp.n. 40(35) Body small, BL $6 \mathrm{~mm}$. Elytra with microsculpture isodiametric to barely transverse; seta $\mathrm{d} 2$ inserted before
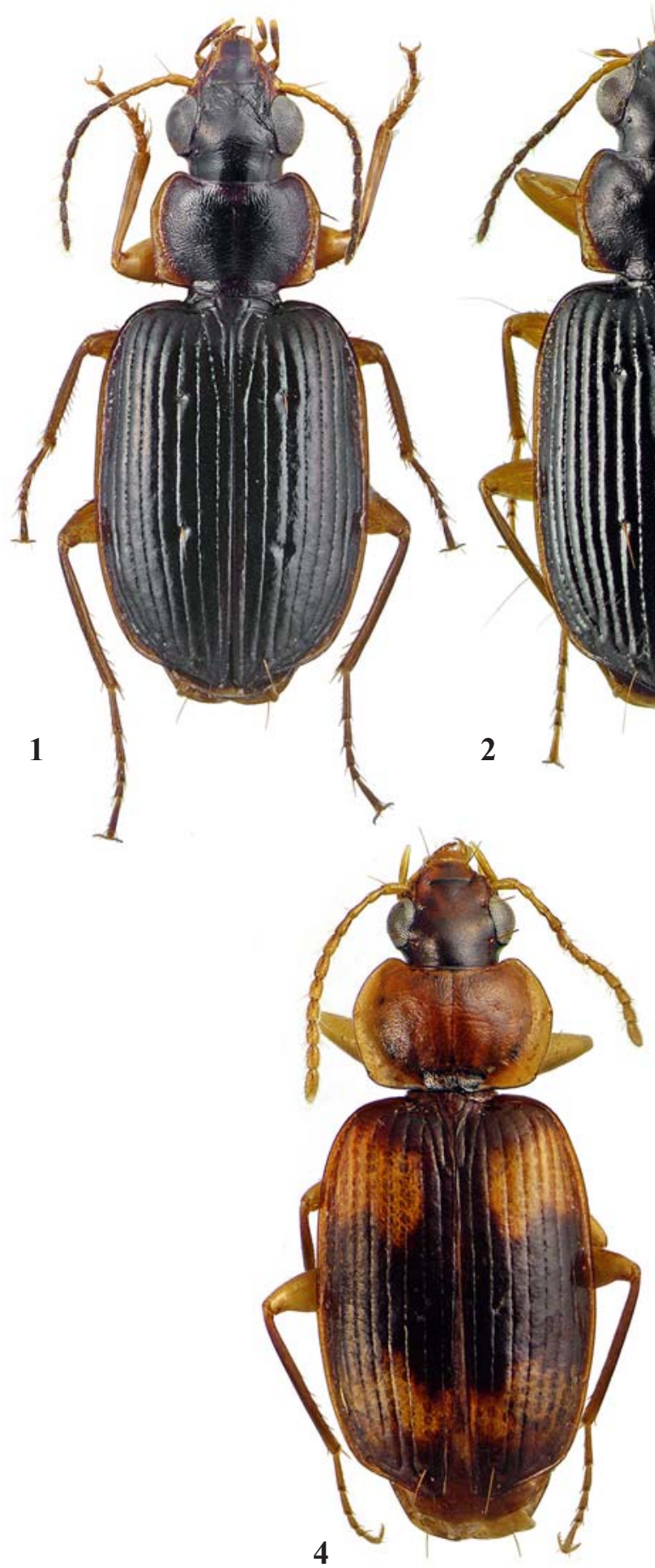

2
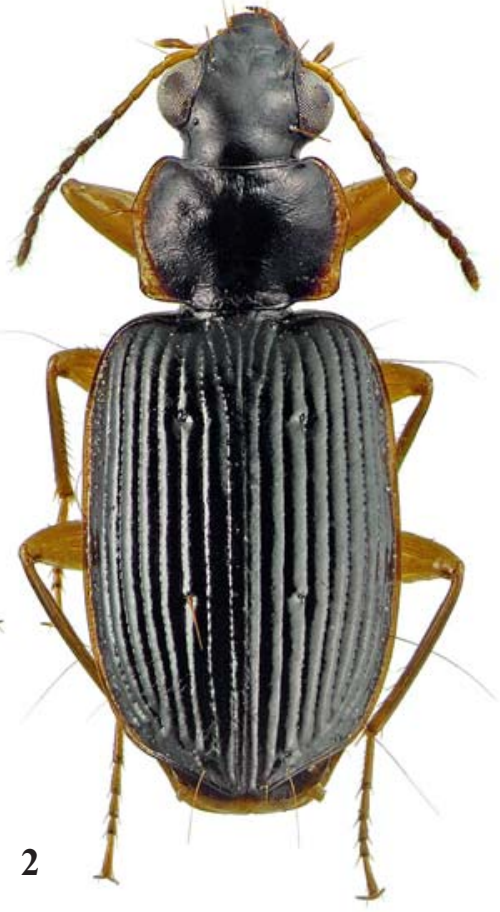

3
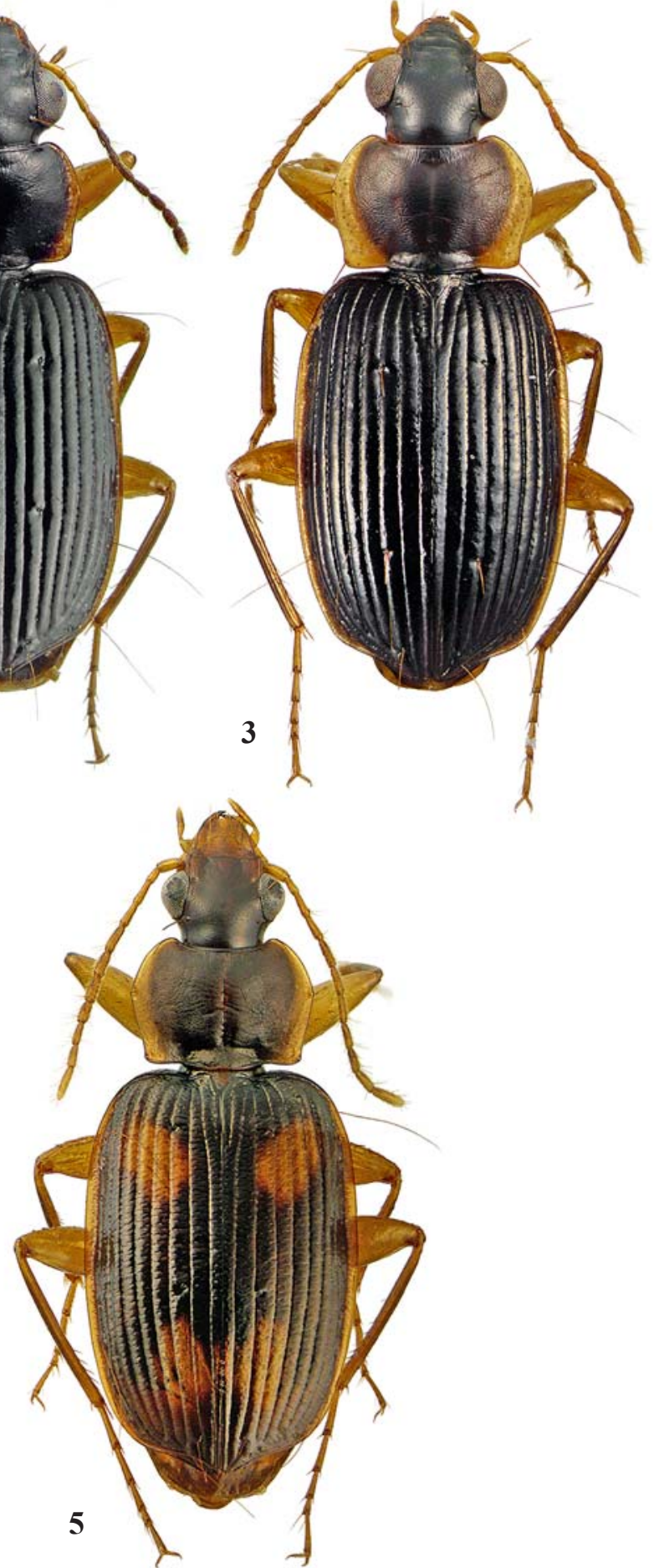

Figs 1-5. Dorsal habitus: 1 -Amphimenes piceus, lectotype; 2 -A. subcostatus sp.n., holotype; 3 - A. marginicollis sp.n., holotype; $4-$ A. ruficollis sp.n., holotype; $5-$ A. similis sp.n., $\sigma^{7}$ paratype from Kon Chu Rang NP.

Рис. 1-5. Габитус дорзально: 1 - Amphimenes piceus, лектотип; 2 - A. subcostatus sp.n., голотип; 3 - A. marginicollis sp.n., голотип; $4-$ A. ruficollis sp.n., голотип; $5-$ A. similis sp.n. , паратип $\bigcirc^{7}$ из национального парка Контюранг. 
middle, D2/EL 0.37-0.40. — Northern Vietnam (Lao Cai)....... 3.7. A. (s.str.) tonkinensis sp.n. 41(34) Discal elytral setae two, d1+d3. Body small, BL 5.5-

$7 \mathrm{~mm}$. Eyes slightly to very strongly (forma minuta) reduced. - Southern Vietnam (Lam Dong, Dak Lak)..

A. (s.str.) medius Fedorenko, 2010

42(19) Elytral interval 3 with two setae, d2 $+d 3$. Mostly apterous species.
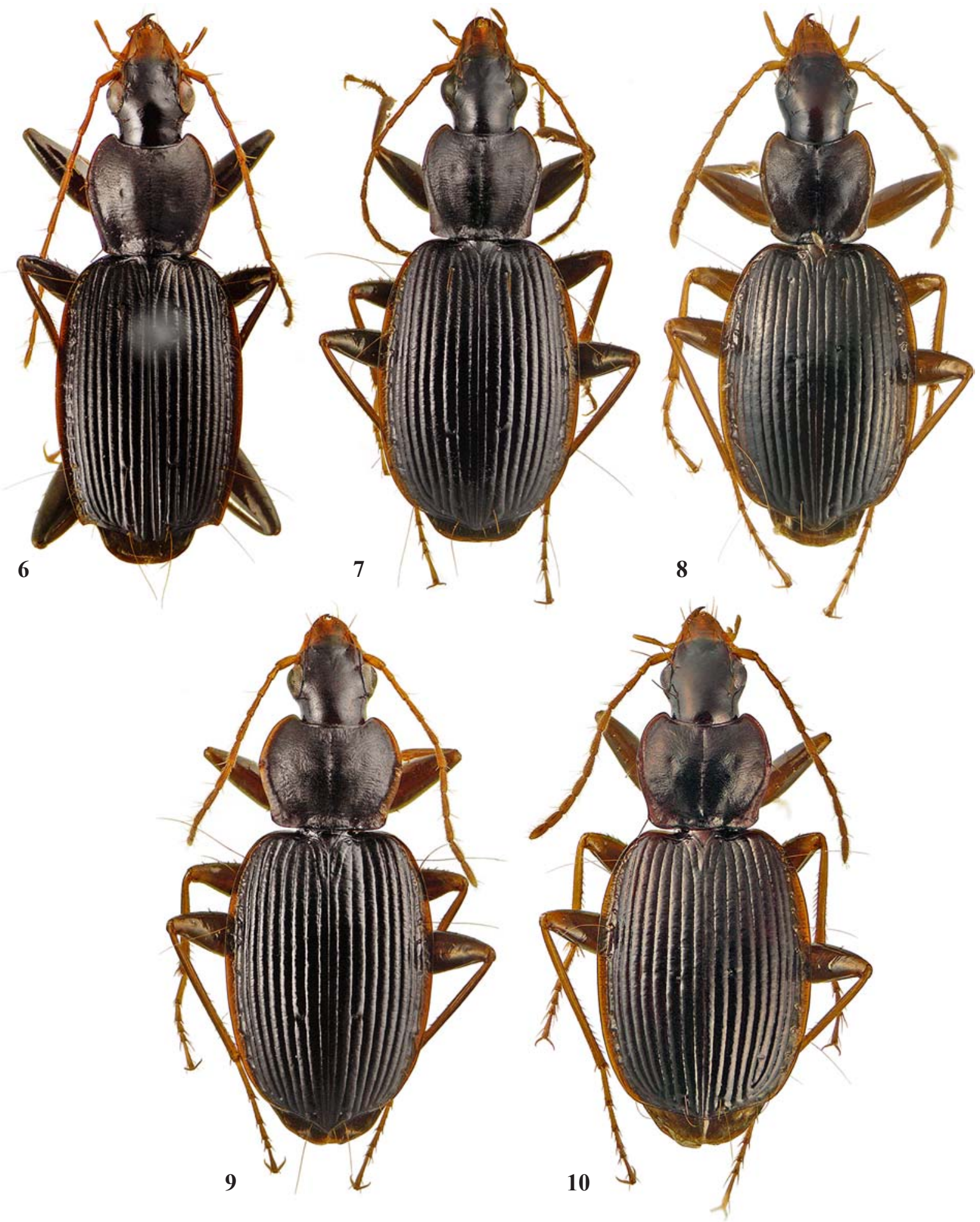

Figs 6-10. Dorsal habitus: 6 - Amphimenes acutipennis sp.n., $0^{7}$ paratype from Kon Plong District; 7 - A. basipunctatus sp.n., holotype; $8-A$. tonkinensis sp.n., holotype; $9-$ A. konplongensis sp.n., holotype; $10-$ A. femoralis sp.n., $\bigcirc^{7}$ paratype.

Рис. 6-10. Габитус дорзально: 6 - Amphimenes acutipennis sp.n., паратип $0^{7}$ из округа Конплонг; 7 - A. basipunctatus sp.n., голотип; $8-$ A. tonkinensis sp.n., голотип; $9-$ A. konplongensis sp.n., голотип; $10-$ A. femoralis sp.n., паратип $0^{7}$. 
43(60) Antennae long, surpassing base of pronotum by at least two apical segments. Pronotal apex deeply sinuate and entirely beaded. Body apterous and larger, BL 5.3$8.5 \mathrm{~mm}$.

44(51) Discal seta d2 distinctly behind middle, D2/EL 0.55 0.71. Elytra longer, EL/EW 1.39-1.51, and conspicuously cross-striated throughout ......... the planicollis-group

45(50) Elytral microsculpture consisting of dense transverse lines. Tarsomere 5 with two pairs of ventral setae.

46(47) Body large, BL 7.6-9.2 mm. Pronotum with sides indistinctly sinuate in front of basal angles; lateral margin strongly reflexed, very wide basally, finely yet distinctly rugulose-punctate. Femora infuscated but apices. - Northern Vietnam (Lao Cai, Vinh Phuc, Cao Bang)

3.10. A. (s.str.) reflexicollis Fedorenko, 2010

47(46) Body small, BL 5.2-7.5 mm. Pronotum distinctly sinuate on sides in front of basal angles; reflexed lateral margin moderately wide and impunctate. - Northern Vietnam (Nghe An).

48(49) Legs reddish-yellow. BL 5.2-6.6 mm. Median lobe of aedeagus with a triangular dilation at left margin a third from apex (same as in Fig. 35)

A. (s.str.) planicollis Fedorenko, 2010

49(48) Legs red, with femora infuscated but apices. Body barely larger in general, BL 5.8-7.5 mm. Median lobe of aedeagus with a triangular dilation at middle of left margin (Fig. 37) ......... 3.9. A. (s.str.) bicoloripes sp.n.

50(45) Elytral microsculpture consisting of very transverse meshes. Femora infuscated but apices. At least pro- and mesotarsomere 5 bisetose ventrally. Sides of pronotum mostly distinctly sinuate before base. BL $6-7.1 \mathrm{~mm} . . .$.

3.8. A. (s.str.) konplongensis sp.n.

51(44) Discal seta d2 before middle, sometimes just behind middle: D2/EL 0.40-0.55. Elytra shorter, EL/EW 1.29_ 1.42 , with cross-striated sculpture mostly confined to base only the brunneus-group

52(57) Elytral microsculpture consisting of transverse meshes. Elytra nearly smooth, with cross-striation very superficial, confined to base and/or hardly traceable in basal half or third.

53(56) Legs unicolourous reddish-yellow.

54(55) Body small, BL $5.7 \mathrm{~mm}$. Head and pronotum rather dull from coarse isodiametric microsculpture. Elytra with slightly to strongly transverse microsculpture and crossstriation hardly traceable in basal half. - Vietnam ...... A. (s.str.) brunneus (Kirschenhofer, 1999)

55(54) Body larger, BL $6.3 \mathrm{~mm}$. Head and pronotum more shiny due to microsculpture superficial, isodiametric rather than granulate, and still more superficial at middle of pronotum. Elytral microsculpture strongly transverse and cross-striation confined to base. - Northern Vietnam (Vinh Phuc) ........ A. (s.str.) kabakovi Fedorenko, 2010

56(53) Femora infuscated except apically. BL $6.2-6.7 \mathrm{~mm}$ Profemur with a large ventrobasal tubercle in male. Northern Vietnam (Cao Bang)

3.11. A. (s.str.) femoralis sp.n.

57(52) Elytral microsculpture consisting of dense transverse lines not forming distinct meshes.

58(59) Elytral cross-striated sculpture very superficial and confined to base. Pronotum broader, slightly more than 1.5 times as wide as long and as much as wide as head. Body larger, BL $7.2 \mathrm{~mm}$. - Northern Vietnam (Thai Nguen) ................... A. (s.str.) nitidus Fedorenko, 2010

59(58) Elytral cross-striated sculpture distinct throughout or obliterated at apex only. Pronotum two fifths wider than long at the most and less than half wider than head. Body smaller, BL 5.3-6.2 mm. - Northern Vietnam (Phu Tho) A. (s.str.) planipennis Fedorenko, 2014 60(43) Antennae short, not surpassing base of pronotum. Pronotum almost truncate apically, with apical bead obliterate medially. Body very small, BL 4.7-4.9 mm. legs pale ................................................. the rufipes-group

61(62) Elytral intervals smooth, with coarse isodiametric microsculpture on disc. Body apterous. - Southern and central Vietnam (Lam Dong)

A. (s.str.) rufipes Fedorenko, 2010

62(61) Elytral intervals distinctly cross-striated, with very transverse microsculpture. Body macropterous, BL 4.3$5.2 \mathrm{~mm}$. Apical bead of pronotum medially very thin or obliterate. Elytral seta d2 inserted at or slightly before middle - Southern and Central Vietnam (Dak Lak, Gia Lai, Kon Tum, Quang Nam)

3.12. A. (s.str.) micros Fedorenko, 2014

\section{Subgenus Amphinemes Fedorenko, subg.n.}

Type species: Brachichila rugulipennis Bates, 1892.

DIAGNOSIS. Macropterous species of rather robust facies, with trimaculate elytral pattern, lateral margins of both pronotum and elytra, legs, antennae and mouthparts pale. Eyes fairly large and rather prominent. Elytral intervals densely cross-striated; interval 3 with three setae, including $\mathrm{d} 1$ inserted close to base (D1/EL ca 0.15$)$ and d2 at middle (D2/EL 0.43-0.53). Elytral microsculpture consisting of very transverse meshes or dense transverse lines.

NAME. Masculine, anagram based on Amphimenes.

DISTRIBUTION. Indochina east to southern China (Hong-Kong).

\subsection{Amphimenes (Amphinemes) rugulipennis (Bates, 1892)}

Bates, 1892: 406 (Brachichila; Thagata, Tenasserim); Fedorenko, 2010: 22,24

MATERIAL. Southern Vietnam: $O^{7}$ (SIEE; D. Fedorenko leg.), Binh Phuoc, Bu Gia Map National Park, $12^{\circ} 11^{\prime} 37^{\prime \prime N} 107^{\circ} 12^{\prime} 21^{\prime \prime}$, h=350-540 m, 26.IV-4.V.2013; O (SIEE), Dak Lak, Chu Yang Sin National Park, $12^{\circ} 25^{\prime} 25^{\prime \prime} \mathrm{N} 108^{\circ} 21^{\prime} 53^{\prime \prime} \mathrm{E}$, Krong Kmar River, upper flow, $\mathrm{h}=970 \mathrm{~m}, 15-30 . \mathrm{V} .2014$.

DISTRIBUTION. This species is known to be widespread in Indochina, being recorded in Tenasserim, Myanmar (type locality); Thailand; southern (Dong Nai), and northern (Nghe An) Vietnam, therefore the above listed records are expected. - The record in Hong Kong [Aston, 2016] apparently refers to the following species.

\subsection{Amphimenes (Amphinemes) maculatus Fedorenko, 2010}

Fedorenko, 2010: 22, 26. — rugulipennis: Aston, 2016 (wrong identification).

MATERIAL. Vietnam: $\sigma^{7}$, (SIEE), Binh Phuoc, Bu Gia Map National Park Park, $12^{\circ} 11^{\prime} 37^{\prime} \mathrm{N} 107^{\circ} 12^{\prime} 21^{\prime \prime} \mathrm{E}, \mathrm{h}=350-540 \mathrm{~m}, 26$.IV4.V.2013, D. Fedorenko leg.; $\bigcirc^{7}$ (SIEE) Northern Thailand, Mae Hong Son, env. Pai, 19.3583 'N 98.4468'E, 300 m, 15-24.XII.2010, $\mathrm{K}$. Tomkovich leg.

DISTRIBUTION. The records listed extend the species range from the only known locality, Cat Tien National Park in southern Vietnam (Dong Nai), far westward. Under the name $A$. rugulipennis, this species has also been recorded in Hong Kong [Aston, 2016]. This follows from the fact that I see no difference between examined aedeagi of $A$. maculatus and that (digital image) of an undetermined Amphimenes species from Hong Kong, received from Mr. Paul Aston years ago. 


\subsection{Amphimenes (Amphinemes) similis} Fedorenko, sp.n.

Figs 5, 13-14.

MATERIAL. Holotype $\sigma^{7}$ (ZMMU) labelled: 'Vietnam, Gia Lai Province, $\sim 50 \mathrm{~km}$ N of An Khe, Kon Chu Rang Nat[ure]. Reserv[e]., $14^{\circ} 31^{\prime} \mathrm{N} 108^{\circ} 32^{\prime} \mathrm{E}, \mathrm{h}=1000-1040 \mathrm{~m}, 24 . \mathrm{V}-2 . V I .2016$, D.Fedorenko leg.'. Paratypes (ZISP, SIEE): $60^{7} 0^{2}, 3$, +9 , same data; + , 'Vietnam, Kon Tum Prov[ince]., Kon Plong Distr[ict]., 144' N $/ 108^{\circ} 19^{\prime} 10^{\prime \prime}$, Dak Khe River, $\mathrm{h}=1030$ m, 8-23.IV.2015, D.Fedorenko leg.'; + same locality, except for ' $14^{\circ} 45^{\prime} \mathrm{N} / 108^{\circ} 17^{\prime} 51^{\prime}$ "E, env. ngock Boc 1 Mt., h=1300-1400 m, 8-10.VI.2016, D.Fedorenko leg.'; 3 $0^{7} \sigma^{7}, 29$ 'Vietnam, Quang Nam Prov., Nam Gian Distr., Song Thanh Natn. Park, $15^{\circ} 32-33^{\prime} \mathrm{N} / 103^{\circ} 22-23^{\prime} \mathrm{E}, \mathrm{h}=1100-1230 \mathrm{~m}, 23 . \mathrm{IV}-$ 11.V.2019, leg. D. Fedorenko'; $12 \sigma^{7} \sigma^{7}, 13$ 우, same data except $15^{\circ} 34^{\prime} 16^{\prime \prime} \mathrm{N} / 107^{\circ} 22^{\prime} 44^{\prime \prime} \mathrm{E}, \mathrm{h}=1030 \mathrm{~m}$; $20^{\top} \mathrm{O}^{\top}$, 2 우, same data except $15^{\circ} 34^{\prime} 26^{\prime} \mathrm{N} / 107^{\circ} 23^{\prime} 30^{\prime \prime} \mathrm{E}, \mathrm{h}=1070-1170 \mathrm{~m}$; ㅇ (MPSU), 'Vietnam, C[entral]. Annam, prov[ince]. Quang Binh, Minh Hoa distr. Ke Bang, 8 km SO[=SE] env. Yen Hop, 2-8.IV.1999 (Dalat campus), leg. S. Kruskop'. Aedeagus examined in six males.

DESCRIPTION. Body (Fig. 1) macropterous, BL 6.1-7.4 $\mathrm{mm}$. Elytra brown to dark brown. Head and pronotum dirty red or reddish-brown, sometimes brown, with head a little darker than pronotum; legs, antennae, mouthparts, clypeus, reflexed lateral margins of pronotum and of elytra, and two, fairly large, spots on each elytron reddish yellow; tibiae with darker stripes along outer margins. Anterior pale spot rounded, slightly oblique toward suture, spanning intervals $3-6$ or 3-7 from d1 to midway between $\mathrm{d} 1$ and $\mathrm{d} 2$ (mostly slightly surpassing $\mathrm{d} 1$ anteriorly and reaching $2 / 3$ distance between $\mathrm{d} 1$ and $\mathrm{d} 2$ posteriorly). Posterior spots oblong, on intervals $1-4$ or $1-5$, merging into common U-shaped macula excavated anteriorly on intervals $1-2$. Both spots subequally distant from $\mathrm{d} 2$. Head and pronotum dull from granulate isodiametric microsculpture. Elytra shiny, with a well-developed cross-striated sculpture and superficial yet distinct microsculpture consisting of narrow transverse meshes.

Head as for the group: eyes large, hemispherical; genae very short and smoothly extended into neck. Clypeus very convex at apical margin, with straight basal margin. Frontal foveae nearly indistinct, except for small deep pits at laterobasal angles of clypeus.

Pronotum transverse, PW/PL 1.50-1.62 (mean 1.56, $\mathrm{n}=8$ ), PW/HW 1.42-1.57 (1.49), broadest at anerolateral seta, half
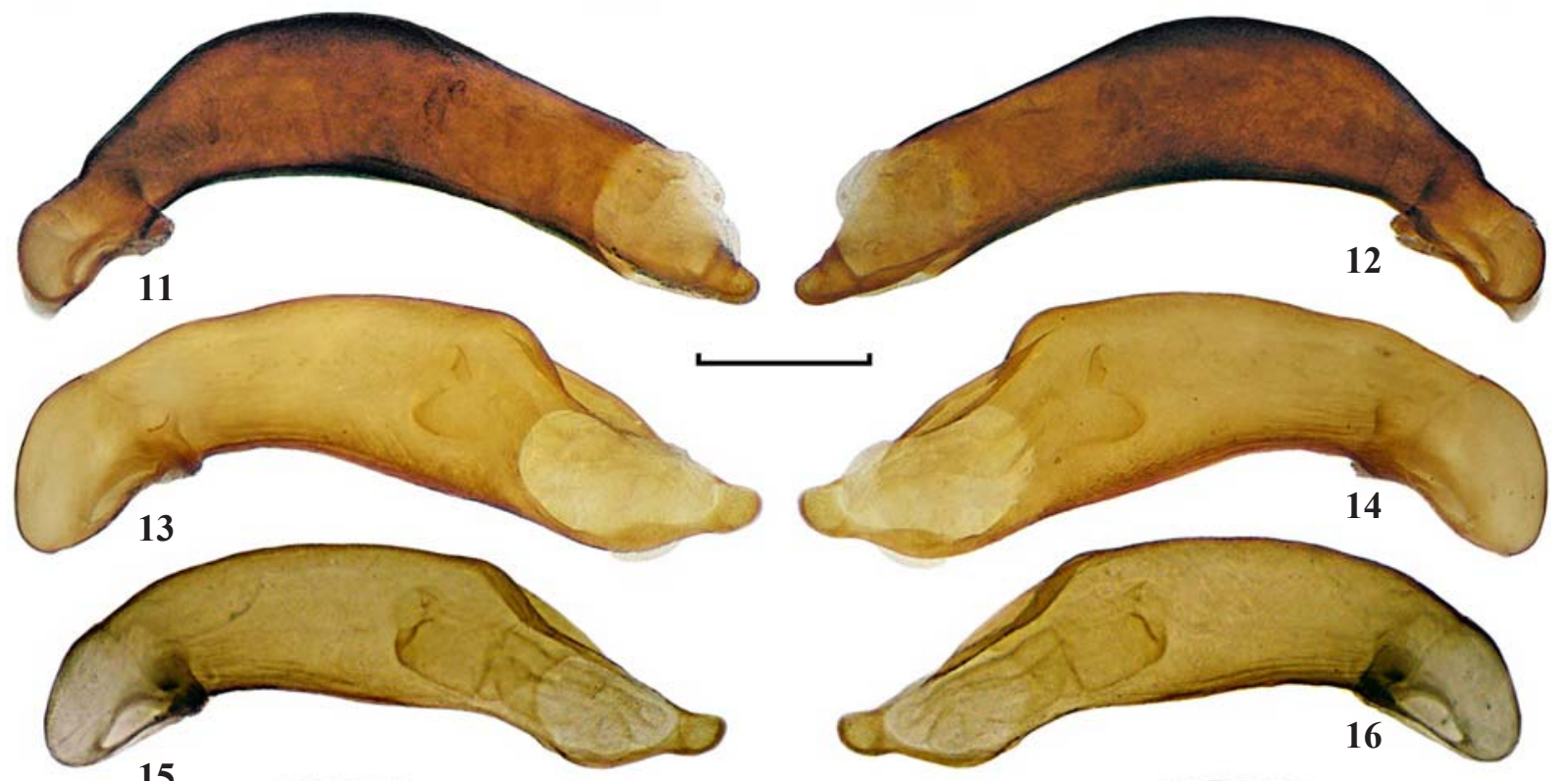

15
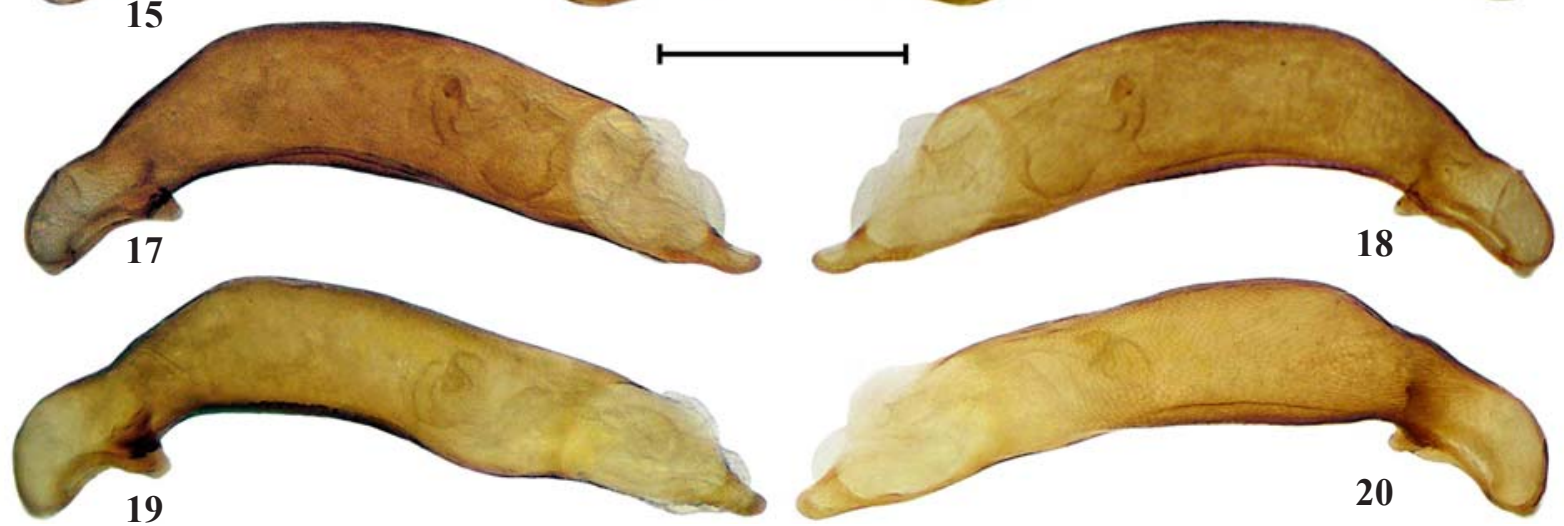

Figs 11-20. Median lobe of aedeagus: 11-12 - Amphimenes acutipennis sp.n.; 13-14 — A. similis sp.n.; 15-16 - A. guttatus; 1718 - A. basipunctatus sp.n.; 19-20 - A. femoralis sp.n.; 11, 17, 19 - left aspect; 13, 15 - left ventrolateral aspect; 12 , 18, 20 - right aspect; 14, 16 - right ventrolateral aspect. Scale bars: $0.5 \mathrm{~mm}$.

Рис. 10-19. Средняя доля эдеагуса: 11-12 — Amphimenes acutipennis sp.n.; 13-14 - A. similis sp.n.; 15-16 - A. guttatus; 17-18 A. basipunctatus sp.n.; 19-20 - A. femoralis sp.n.; 11, 17, 19 - слева; 13, 15 - слева и снизу; 12, 18, 20 - справа; 14, 16 - справа и снизу. Масштаб: 0,5 мм. 
wider at base than at apex, PB/PA 1.48-1.58 (1.51). Sides rounded in apical two thirds or slightly angulate at anterolateral seta and nearly straight just before, gently sinuate in front of basal angles. Base with median part on a level with basal angles or slightly produced caudad; basal angles right to slightly obtuse and blunt. Apex deeply sinuate; apical angles porrect and almost adherent to neck, with blunt or narrowly rounded apices. Basal bead obsolete or interrupted just in the middle; apical bead fine and entire. Explanate lateral margin slightly reflexed, very narrow just behind apical angles, becoming increasingly wide basad, mostly very wide in basal third. Disc moderately convex, very shallowly rugulose, more rugulose along sides, a third from base without or with a pair of shallow paramedian foveae equidistant from median line and lateral edge. Median line deep between apical bead and basal transverse impression, which is fairly deep and barely angulate forward. Basal foveae as small and deep impressions just in front of meeting points of lateral lobes and median part of base.

Elytra rather square, EW/EL 1.42-1.50 (1.46), EW/PW $1.43-1.52$ (1.47), broadest at about middle, with humeri and posterolateral angles widely rounded, sides nearly parallelsided or very slightly rounded in middle third. Basal margin transversely straight, slightly convex, barely concave close to mesothoracic peduncle. Apical truncature oblique, almost indistinctly sinuate; apices each blunt or very narrowly rounded. Striae deep, crenulate; intervals flat, slightly convex before apex; 6th and 7th convex behind humerus. Interval 3 with three setae, D1/EL $0.13-0.17(0.15, \mathrm{n}=5 \times 2), \mathrm{D} 2 / \mathrm{EL}$ $0.46-0.56$ (0.50), D3/EL 0.91-0.92 (0.92). wide.

Metepisternum long, $1.46-1.58(\mathrm{n}=3)$ times as long as

Tarsomere 5 with 1-2 pairs of ventral setae, proximal seta often much shorter than distal one. In male, profemur with no ventrobasal tubercle, mesotrochanter with a minute, nearly indistinct, tubercle; mesotibia with five tubercles along inner margin

Aedeagus (Figs 13-14): similar to that of A. guttatus (Figs 15-16), except for median lobe in lateral view distinctly broader before apical orifice than behind basal bulb (vs. subequally wide), apical orifice longer, $2 / 3$ as long as distance between dorsal swell and base of apical lamella ( $v s$. half as long), and internal sac slightly different in shape.

DIAGNOSIS. This species is very similar to recently described A. guttatus, except that the latter is barely darker in ground-color, with elytral striae more distinctly crenulate, preapical elytral macula slightly constricted at suture before and behind; and pronotal base and reflexed lateral margin barely narrower. Males of A. guttatus are additionally distinctive in having profemur with a conspicuous ventrobasal tubercle and mesotibia with only four tubercles along inner margin. Aedeagus is distinctive, too.

DISTRIBUTION. Central Vietnam (Gia Lai, Kon Tum, Quang Nam, Quang Binh).

NAME. Refers to high similarity of this species to $A$. guttatus.

HABITATS AND HABITS. All the specimens of the type series were taken under exfoliated bark scales of living trees in mixed monsoon forests.

\section{Subgenus Amblops Andrewes, 1931, stat.n.}

Andrewes, 1931: 520.

Type species: Amblops piceus Andrewes, 1931 (by original designation)

DIAGNOSIS. See combination of characters $(1-4)$ below and the key.
DISTRIBUTION. Widespread in the Oriental region from northern India through Indochina to southern China (Taiwan).

COMMENTS. This subgenus was described by Andrewes [1931] as a genus allied to Brachichila Chaudoir, 1869 and somewhat to Holcoderus Chaudoir, 1869 and Tantillus Chaudoir, 1869. He mentioned two, large, tuberculate punctures (d1 and d2) on the elytral stria 3 as the main distinctive feature of Amblops, and toothed (vs. edentate) mentum, combined with a clearly longer labrum, as what distinguished Amblops from Brachichila. However, the latter combination differentiates also Amphimenes from Brachichila, and posterior elytral discal seta $(\mathrm{d} 3)$ is actually present in Amblops piceus. It follows that Amblops differs from Amphimenes by only having: (1) the eyes large and prominent, (2) the elytral striae punctate, (3) no elytral cross-striation, and (4) the antennae being barely shorter, with (5) segments 5-11 infuscated. The characters (1), (3) and (4) taken separately each have also been observed in some Amphimenes. Specifically, the eyes are large in $A$. rugulipennis, some species of different species groups have elytral intervals with cross-striations vestigial or no, and still shorter antennae are peculiar to the rufipes-group. Besides, A. absensacidus Hunting et Yang, 2019 has been described with no reference to Amblops, but it has all features of this genus, except for entirely pale and barely longer antennae. Lastly, A. ruficollis sp.n. is transitional to Amphimenes in having the eyes slightly flattened, elytral striae almost indistinctly punctate, and elytral discal setae non-foveate.

These facts, combined with the metacoxal tubercle present in an examined male paratype of A. piceus, almost fill morphological gap between Amblops and Amphimenes with themselves. For the reason Amblops is here downgraded to subgenus of Amphimenes.

The subgenus includes five macropterous arboricolous species arranged into two species groups.

The piceus species group.

\subsection{Amphimenes (Amblops) piceus}

(Andrewes, 1931), comb.n.

Figs 1, 27-28, 32.

Andrewes, 1931: 521 (Amblops; Dehra Dun, North India).

MATERIAL. Two syntypes (BMNH): $\sigma^{7}$ with four labels: 'Dehra Dun, Jharipani 5,222 ft.', 'Bought from Staudinger \& BangHaas, 1930', 'Type' [red], 'Amblops piceus, Type Andr.[hw], H.E.Andrewes det.'; $\sigma^{7}$ mounted on back, with same labels, except for 'Cotype' (white circle margined with green) substituted for the fourth label. The former syntype is here designated as lectotype. Also, digital image of a syntype at https://carabidae.org.

REDESCRIPTION. Unnecessary, except for the following additions: Body (Fig. 1). Pronotum broadest 0.29 times from apex, with median part of base distinctly produced and 2.67 times as wide as lateral lobes; PW/PL 1.48-1.53 (1.51, $\mathrm{n}=3), \mathrm{PW} / \mathrm{HW} 1.20-1.24$ (1.23), PB/PA 1.37-1.40. EL/EW $1.40-1.47$ (1.43), EW/PW 1.55-1.60 (1.58); D1/EL 0.24, D2/EL 0.63-0.66 (0.65), D3/EL 0.92-0.94 (0.93). Mesotibia with a minute preapical fissure instead of tubercles. Tarsomere 5 with one pair of long ventral setae in apical half.

Aedeagus (Figs 27-28, 32): median lobe in ventral view barely wider a third from base than just distal to basal bulb; apex rounded and fairly small.

DISTRIBUTION. Known from a few localities in the environs of Dehra Dun, northern India.

HABITATS AND HABITS. Andrewes [1931] reported that most of the syntypes were taken under bark, including eleven under bark of Pinus longifolia. 


\subsection{Amphimenes (Amblops) subcostatus}

Fedorenko, sp.n.

Figs 2, 29-30, 34.

MATERIAL. Holotype + (ZMMU) labelled: 'Vietnam, Dak Lak Province, Chu Yang Sin Nat[io]n[al]. Park, $12^{\circ} 25^{\prime} 25^{\prime \prime} \mathrm{N} /$ $108^{\circ} 21^{\prime} 53^{\prime \prime}$, Krong Kmar riv[er]., upper flow, h=970 m, 1530.V.2014, D.Fedorenko leg.' . Paratype O' (SIEE): 'Laos, Prov[ince] Vientiane, env. Van Vieng, $18^{\circ} 55^{\prime} 12^{\prime \prime} \mathrm{N} / 102^{\circ} 26^{\prime} \mathrm{E}, \mathrm{h}=\sim 230 \mathrm{~m}$, at light, 7-9.XI.2015, leg. I.Melnik'.

DESCRIPTION. Body (Fig. 2) macropterous, small, BL 5.2-5.4 mm, shiny black. Mouthparts, basal four antennomeres, legs, including coxae, as well as sternum between coxae and in front of metacoxae, reddish-yellow; tibiae and tarsi indistinctly infuscated while mandibles, hypomera, reflexed margins of both pronotum and elytra barely more so; metaventrite and abdomen reddish-brown; antennomeres 511 dark brown. Head and pronotum with isodiametric microsculpture, more superficial on vertex and neck, nearly granulate before, granulate along pronotal apex and base; elytra with superficial yet distinct microsculpture consisting of very transverse yet large meshes.

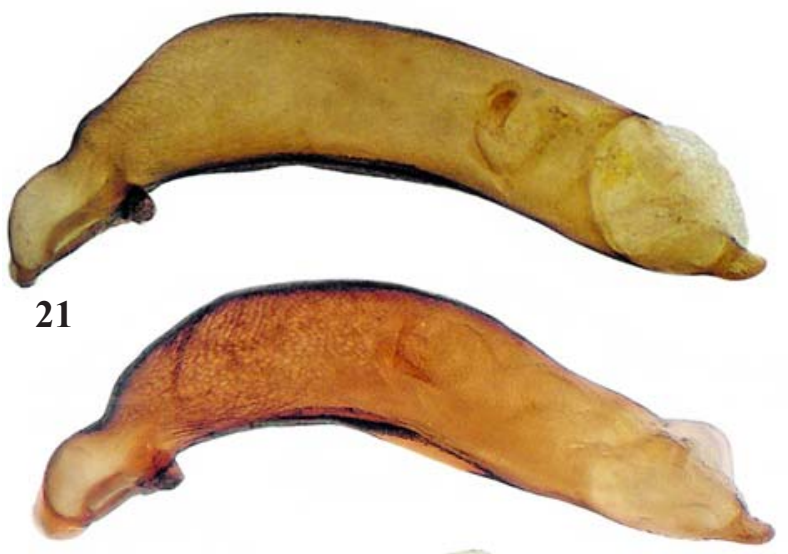

23

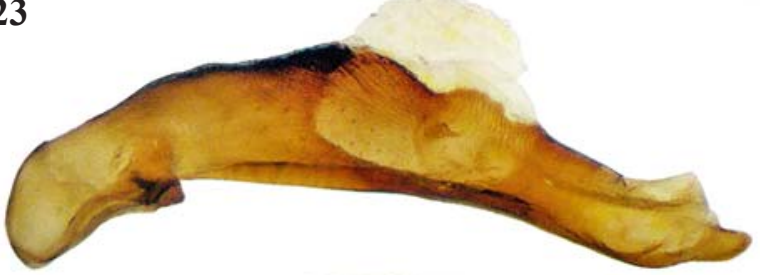

25

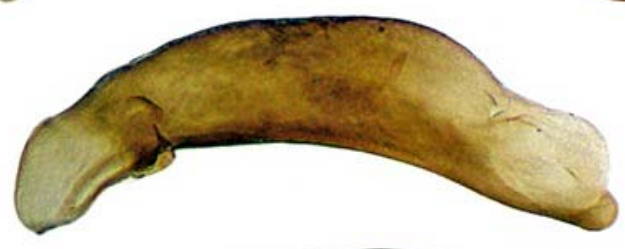

Head: eyes large and hemispherical; genae nearly indistinct. Posterior supra-ocular seta on a level with posterior margin of eye. Antennae short, not quite reaching basal angles of pronotum.

Pronotum quadrate, slightly transverse, PW/PL 1.491.54, PW/HW 1.24-1.26, wider at base than at apex, PB/PA 1.39-1.41, broadest a third from apex. Sides rounded in apical two thirds, indistinctly angulate at and straight on each side of anterolateral seta, gently sinuate in front of basal angles, which are obtuse and rounded at tips. Base with median part convex, distinctly produced beyond and twice as wide as lateral lobes; these slightly oblique forward and rounded at basal angles; basal bead obsolete in the middle. Apex evenly concave and very finely beaded; apical angles blunt and lightly projecting forward. Disc very convex, finely and densely rugulose. Lateral margin explanate and moderately reflexed, narrow in apical half, slightly wider basad. Median line entire and deep. Both transverse impressions, basal and apical, shallow. Basal foveae small, deep and rounded. Paramedian foveae very small and nearly imperceptible.
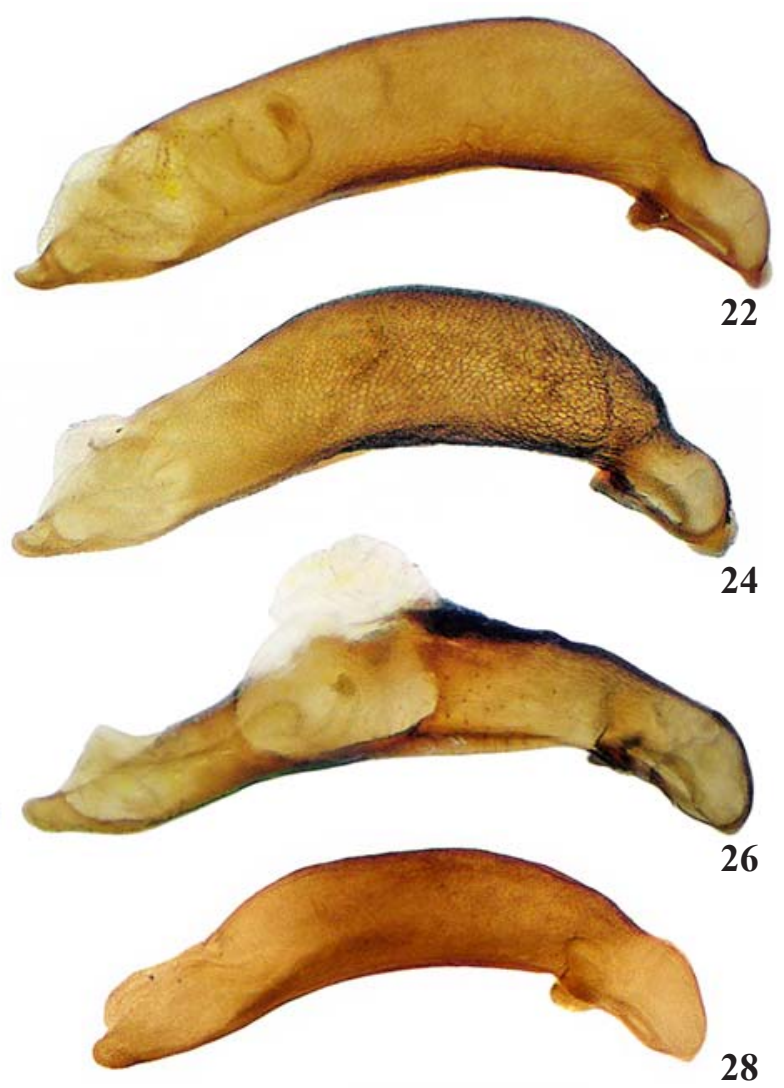

28

29

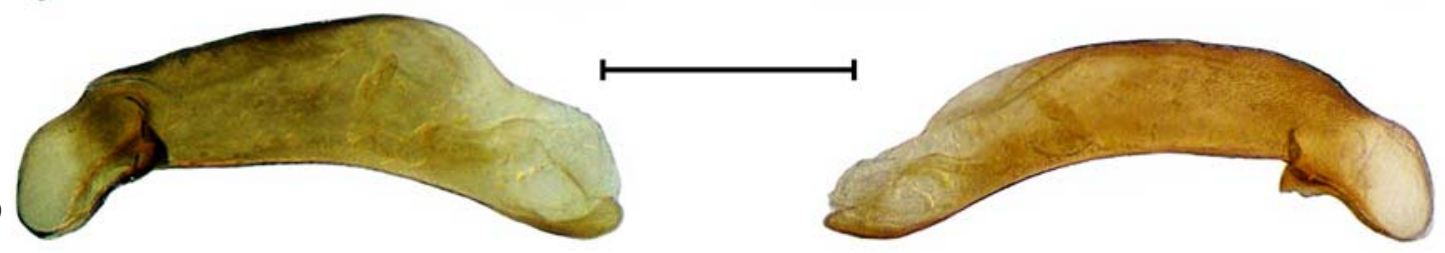

Figs 21-30. Median lobe of aedeagus: 21-22 - Amphimenes konplongensis sp.n.; 23-24 - A. bicoloripes sp.n.; 25-26 - A. marginicollis sp.n.; 27-28 - A. piceus; 29-30-A. subcostatus sp.n.; 21, 23, 25, 27, 29 - left aspect; 22, 24, 26, 28, 30 - right aspect. Scale bar: $0.5 \mathrm{~mm}$.

Рис. 21-30. Средняя доля эдеагуса: 21-22 — Amphimenes konplongensis sp.n.; 23-24 — A. bicoloripes sp.n.; 25-26 - A. marginicollis sp.n.; 27-28 - A. piceus; 29-30-A. subcostatus sp.n.; 21, 23, 25, 27, 29 - слева; 22, 24, 26, 28, 30 - справа. Масштаб: 0,5 мм. 
Elytra nearly square, EL/EW 1.45-1.51, EW/PW 1.461.48 , broadest at middle, nearly parallel-sided in middle third, with humeri and posterolateral angles widely rounded. Apical truncature oblique and barely sinuate; extreme apices blunt. Striae deep and finely punctate; intervals convex, more so before apex. D1/EL 0.21-0.23 (0.22), D2/EL 0.60-0.64 (0.62), D3/EL 0.92-0.94 (0.93).

Metepisternum long.

Tarsomere 5 with one pair of ventral setae close to apex. In male, profemur and mesotrochanter without tubercle, mesotibia with one preapical tubercle at inner margin.

Aedeagus (Figs 28-29, 33): as in A. piceus, except for median lobe subtriangular ( $v s$. subequally wide) in ventral view owing two a large rounded swell on left side, with apical lamella distinctly wider and a little upturned.

DIAGNOSIS. Very similar to A. piceus, being distinctive in having the elytra slightly longer and more convex, with striae deep, inner intervals convex and outer intervals very so. Aedeagus is differently shaped as well.

DISTRIBUTION. Southern Vietnam and Laos.

NAME. Refers to the convex to very convex elytral intervals.

HABITATS AND HABITS. The female specimen was taken under exfoliated bark scales of a living tree in a broadleaved monsoon forest.

\subsection{Amphimenes (Amblops) marginicollis \\ Fedorenko, sp.n.}

Figs 3, 25-26, 36.

MATERIAL. Holotype $\sigma^{7}$ (ZMMU) and paratype $\sigma^{7}$ (SIEE) labelled: 'N-Vietnam, Nghe An Prov., Que Phong Distr., Pu Hoat National Park, $19^{\circ} 45^{\prime} 19^{\prime \prime} \mathrm{N} / 104^{\circ} 47^{\prime} 47^{\prime \prime} \mathrm{E}, \mathrm{h}=840 \mathrm{~m}$ 15-27.V.2019, leg.D.Fedorenko'.

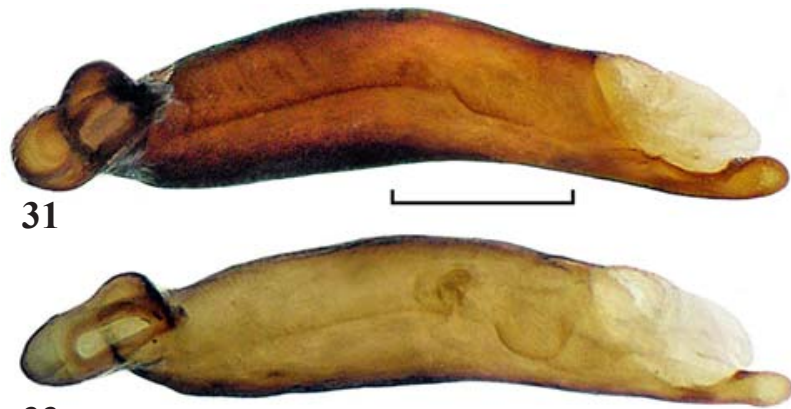

33

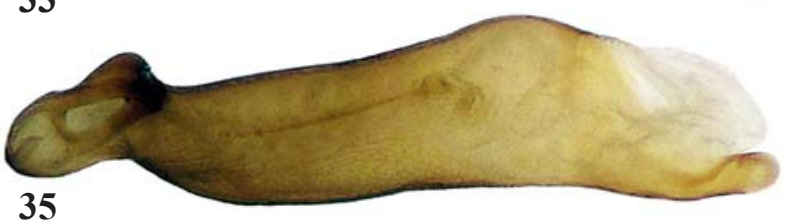

35

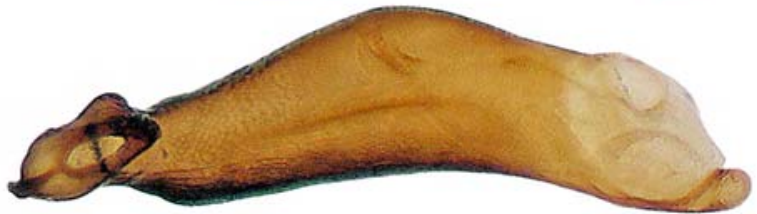

37
DESCRIPTION. As for the previous species, except as follows: Body (Fig. 3) larger, BL 5.9-6.4 mm. Mouthparts (labrum excluded), antennae, legs, reflexed margins of both pronotum and elytra reddish yellow. Underside red within prothorax, along middle of meso- and metaventrites, with abdomen reddish medially, otherwise dark brown.

Antennae reaching basal angles of pronotum.

Pronotum large and transverse, PW/PL 1.57-1.61, PW/ HW 1.40-1.48, half wider at base than at apex, PB/PA 1.471.50 , broadest two thirds from apex. Sides rounded in apical three fourths, with basal basal angles nearly right and blunt. Median part of base half wider than lateral lobes. Explanate lateral margin wide in apical half and very wide in basal half. Median line entire and deep. Basal transverse impression deep, apical one shallow medially, obliterate laterally. Basal foveae small, deep and rounded. Paramedian foveae missing.

Elytra a bit more rounded on sides, EL/EW 1.44-1.48, EW/PW 1.35-1.36. Intervals convex in basal third, along sides and close to apex, otherwise inner four or five nearly flat. D1/EL 0.21-0.25 (0.23), seta d1 closer to apex, D2/EL 0.68-0.71 (0.70), D3/EL 0.93-0.95 (0.93). USS anterior (10 US) and posterior (6 US) groups setae slightly separated to almost continuous, consisting of $9+1+6$ setae.

Tarsomere 5 with two pairs of ventral setae. In male, profemur with a distinct, small and blunt tubercle; mesotibia with four preapical tubercles at inner margin.

Aedeagus (Figs 25-26, 36) similar to that of A. absensacidus, except chiefly for median lobe strongly and abruptly desclerotized, i.e., membranous medioventrally.

DIAGNOSIS. Similar to A. absensacidus, except that pronotal sides are sinuate (vs. convex) in front of almost straight (vs. obtuse) basal angles, and aedeagus distinctive.

32

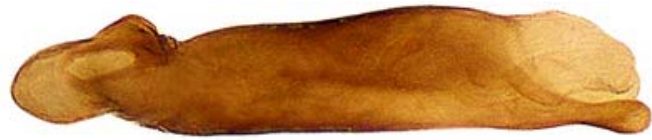

34
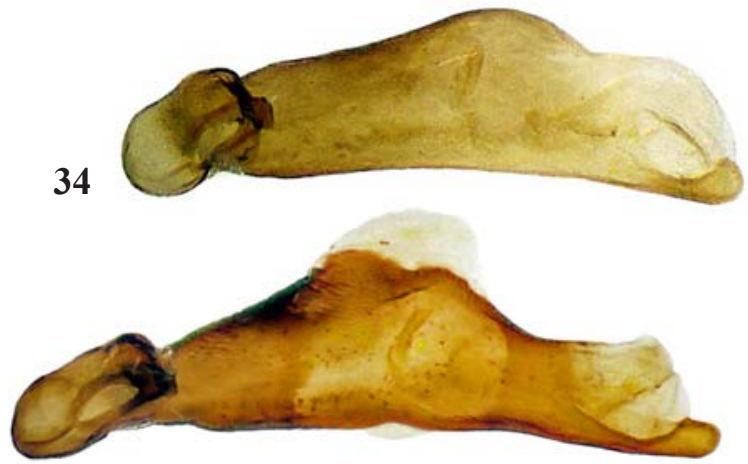

36

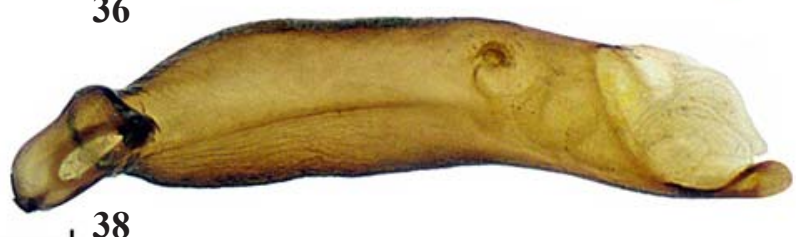

38

Figs 31-38. Median lobe of aedeagus, ventral aspect: 31 - Amphimenes acutipennis sp.n.; 32 - A. piceus; 33 - A. basipunctatus sp.n.; 34 - A. subcostatus sp.n.; 35 - A. femoralis sp.n.; $36-$ A. marginicollis sp.n.; 37 - A. bicoloripes sp.n.; $38-$ A. konplongensis $\mathbf{s p . n .}$ Scale bars: $0.5 \mathrm{~mm}$.

Рис. 31-38. Средняя доля эдеагуса, вентрально: 31 - Amphimenes acutipennis sp.n.; 32 - A. piceus; 33 - A. basipunctatus sp.n.; 34 - A. subcostatus sp.n.; 35 - A. femoralis sp.n.; 36 - A. marginicollis sp.n.; 37 - A. bicoloripes sp.n.; $38-A$. konplongensis sp.n. Масштаб: 0,5 мм. 
DISTRIBUTION. Northern Vietnam.

NAME. Refers to the pale and widely explanate lateral margins of the pronotum.

HABITATS AND HABITS. Both specimens were taken at night, running on trunks of smaller living trees in a broadleaved monsoon forest.

\section{The ruficollis species group.}

This group is introduced here for the only species distinctive in having the body smaller, clypeus and labrum pale, elytral pattern variegated, elytra with striae subpunctate and only two non-foveate discal setigerous pores, $\mathrm{d} 2$ and $\mathrm{d} 3$.

\subsection{Amphimenes (Amblops) ruficollis Fedorenko, sp.n.}

Fig. 4.

MATERIAL. Holotype $0^{7}$ (ZMMU): 'S Vietnam, Lam Dong Prov[ince]., Bi Doup-Nui Ba Nat[ure]. Res[erve]., env[irons]. Long Lanh, $\mathrm{h}=1400 \mathrm{~m}, 12^{\circ} 10^{\prime} 44^{\prime} \mathrm{N}, 108^{\circ} 40^{\prime} 44^{\prime \prime} \mathrm{E}$, window-trap $\mathrm{h}=25 \mathrm{~m}$, 6-10.V.2009, leg.A.Polilov'

DESCRIPTION. Body (Fig. 4) macropterous and very small, BL $4.5 \mathrm{~mm}$. Elytra, mesosternum and metapleura black, base and apex of elytra brownish, head dark brown in posterior half, reddish before, propleura and abdomen brown laterally, ventral side otherwise reddish yellow; mandibles red; pronotum and narrow lateral margin of elytra reddishyellow; palps, antennae, legs and widely explanate lateral margin of pronotum (including hypomera), yellow. Dorsum shiny, head and pronotum slightly dull from rather coarse isodiametric, nearly granulate, microsculpture; sides and apex of pronotal disc with granulate microsculpture becoming slightly transverse on each side of median line behind the middle; elytra with superficial yet distinct microsculpture consisting of slightly to moderately transverse meshes, with admixture of isodiametric meshes here and there. Elytral intervals smooth.

Head: eyes slightly flattened; genae very short. Posterior supra-ocular seta on a level with posterior margin of eye. Antennae short, surpassing pronotal base by apical half of segment 11 .

Pronotum transverse, PW/PL 1.59, PW/HW 1.55, evenly rounded on sides, slightly less so in basal third, broadest two fifths from apex. Base broader than apex, PB/PA 1.39, with median part very slightly projecting caudad; lateral lobes rather strongly rounded close to basal angles; these almost rounded off. Apex deeply sinuate; apical angles porrect, subrectangular, with rounded tips. Disc moderately convex, with very fine transverse wrinkles. Lateral margin explanate and moderately reflexed, becoming increasingly wide from very narrow apically to very wide basally. Median line moderately deep, obliterate behind basal transverse impression, which is well defined and very obtusely angulate forward. Basal foveae indistinct, merged into rather wide and smoothly concave lateral grooves. Paramedian foveae very small and nearly indistinct.

Elytra nearly square, slightly oval, EL/EW 1.44, EW/PW 1.38 , evenly rounded on sides, broadest at middle, with humeri widely rounded yet distinct; posterolateral angles highly obtuse and widely rounded; apices blunt. Apical truncature oblique, indistinctly sinuate. Lateral reflexed margin very narrow just medially, otherwise reduced to a finest bead. Striae rather shallow, crenulate; intervals flat. Interval 3 with two setae, D2/EL 0.56, D3/EL 0.94. USS continuous, consisting of 15 US

Metepisternum 1.45 times as long as wide.

Tarsomere 5 of pro-, meso- and metatarsi with one or $1-$
2 , or two pairs of ventral setae, respectively. In male, profemur with no tubercle, mesotrochanter with a minute tubercle; mesotibia with three preapical tubercles along inner margin.

Aedeagus (lost through mounting): median lobe long, narrow, subequally wide in apical three fourths, almost straight in lateral view, with a well defined apical orifice in almost left position; apex moderately long, tapered, rounded apically, not upturned.

DIAGNOSIS. As for the group.

DISTRIBUTION. Known from the type locality only.

NAME. Refers to the colour of the pronotum.

HABITATS AND HABITS. The only specimen has been collected by a window-trap at $25 \mathrm{~m}$ above ground level in a lowland monsoon broad-leaved forest.

\section{Subgenus Amphimenes s.str.}

- Pseudosinurus Kirschenhofer, 1999: 74 (type species: P. brunneus Kirschenhofer, 1999); Fedorenko, 2014: 306.

DIAGNOSIS. As for the genus [Fedorenko, 2010], except for features of the other subgenera. The subgenus includes macropterous to apterous species, with body more or less slender, dorsum dark unicoloured (except forehead), eyes slightly to strongly flattened, and elytral cross-striated sculpture well-developed in great majority of species included.

DISTRIBUTION. Japan, southern China, including Taiwan, Indochina (Vietnam). New records and discovery of new species in at least Laos are expected in future.

\section{The piceolus species group.}

The group includes six arboricolous species, five macropterous and one, A. asahinai from Taiwan, brachypterous; the latter may form the subgroup or group of itself. Four species included, three from Vietnam (A. bidoupensis, $A$. gracilis, A. montanus) and $A$. ryukyuensis from southern Japan and Taiwan are very similar to one another and thence hard to discriminate. Smaller details of aedeagus, including those of internal sac, are useful for the purpose. Among them, the following four need to be briefly described (Figs. 39-50): (1) $d c$, preapical dorsal carina; (2) $d c l$, shorter left dorsolateral carina, diverging from or from near the base of $d c$; (3) dorsal groove between $d c$ and $d c l$; and (4) $p p l$, left preapical protuberance just outside the base of $d c l$. Dcl does mark the external margin of the dorsal groove, therefore it looks like carina only when the aedeagus is viewed laterally; the deeper dorsal groove (and/or the more prominent $p p l$ ) the more distinct $d c l$.

\subsection{Amphimenes (s. str.) bidoupensis Fedorenko, 2010} Figs 39, 42-44. nam).

Fedorenko, 2010: 23, 27 (Lam Dong Province, southern Viet-

MATERIAL. Type series; additional material includes many specimens, $\sigma^{\top} \sigma^{\top}$ and $O O$ (SIEE, D. Fedorenko leg.), from Central Vietnam: Gia Lai, $50 \mathrm{~km} \mathrm{~N}$ of An Khe, Kon Chu Rang Nature Reserve, $14^{\circ} 312 \mathrm{~N} 108^{\circ} 32^{\prime} \mathrm{E}, \mathrm{h}=1000-1040 \mathrm{~m}, 24 . \mathrm{V}-2 . \mathrm{VI} .2016$; Kon Tum, Kon Plong Distr., $14^{\circ} 43$ 'N, $108^{\circ} 19^{\prime} 10^{\prime \prime} \mathrm{E}$, Dak Khe River, $\mathrm{h}=1030 \mathrm{~m}, 8-23 . I V .2015$; same locality, except for $14^{\circ} 45^{\prime} \mathrm{N}$ $108^{\circ} 18^{\prime} 10^{\prime \prime} \mathrm{E}$, env. ngock Boc $1 \mathrm{Mt}$., h=1200-1300 m, 8-23.IV.2015; Ouang Nam, Nam Gian District, Song Thanh National Park, $15^{\circ} 34^{\prime} 16^{\prime \prime} \mathrm{N} 107^{\circ} 22^{\prime} 44^{\prime \prime} \mathrm{E}, \mathrm{h}=1030 \mathrm{~m}, 23 . \mathrm{IV}-11 . \mathrm{V} .2019$; same data except $15^{\circ} 33^{\prime} 48^{\prime \prime} \mathrm{N} 107^{\circ} 23^{\prime} 22^{\prime \prime} \mathrm{E}, \mathrm{h}=1050 \mathrm{~m}$. Aedeagus examined in 13 males.

DIAGNOSIS. Elytral intervals flat behind middle of disc. Body (BL 6.7-8 mm) and thence aedeagus (Figs 39, 42-44) barely larger than in the other two species from Vietnam in general. Median lobe in lateral view subequally wide be- 
tween basal curve and apical orifice, with $p p l$ indistinct, $d c$ fine, low, not quite reaching apical orifice; $d c l$ diverging from $d c$, straight and rather short, about half as long as distance between base of $d c$ and apical orifice, sometimes vestigial or no. Everted and inflated internal sac (Figs 42-44) with apical bulb $(a)$ apical in position; right lateral bulb (lr) large, curved, directed basad and contiguous to fairly large dorsomedial bulb $(d m)$; left lateral bulb $(l l)$ large.

DISTRIBUTION. The records listed are within the species range that extends from Quang Binh Province in Central Vietnam to Lam Dong Province in southern Vietnam.

\subsection{Amphimenes (s. str.) gracilis}

Fedorenko, 2010

Figs 40, 45-47.

Fedorenko, 2010: 23, 30 (env. Thai Nguen, northern Vietnam).

MATERIAL. Type series. Additional material (SIEE; D. Fedorenko leg.): Northern Vietnam: , , Nghe An, Que Phong Distr., Pu Hoat National Park, $19^{\circ} 45^{\prime} 19^{\prime} \mathrm{N} 104^{\circ} 47^{\prime} 47^{\prime \prime} \mathrm{E}, \mathrm{h}=840 \mathrm{~m}, 15$ 27.V.2019; $30^{7} 0^{7}, 2$, 9 , same data, except $19^{\circ} 46^{\prime} 35^{\prime \prime} \mathrm{N} 104^{\circ} 48^{\prime} 13^{\prime \prime} \mathrm{E}$ $\mathrm{h}=1350 \mathrm{~m}$; , Cao Bang, $40 \mathrm{~km} \mathrm{~W}$ of Cao Bang, Phia Oac — Phia Den Nat. Park, Phia Oac Mt, 22 $26^{\circ} 03^{\prime \prime} \mathrm{N} 105^{\circ} 53^{\prime} 07^{\prime \prime} \mathrm{E}, \mathrm{h}=1300 \mathrm{~m}$, 3-11.X.2018. Aedeagus examined in five males.

DIAGNOSIS. Elytral intervals convex (type specimens) to nearly flat behind middle of disc (the other specimens examined). Aedeagus (Figs 40, 45-47) smaller following a bit smaller body, BL $6.2-7.6 \mathrm{~mm}$. Median lobe in lateral view more robust, distinctly narrower basally than preapically, broadened toward apical orifice in third fourth, with apical orifice more transverse; $d c$ conspicuous, high and reaching apical orifice; $d c l$ starting from near it, longer and more or less sinuate, with a small $p p l$ at base; dorsal groove deep.

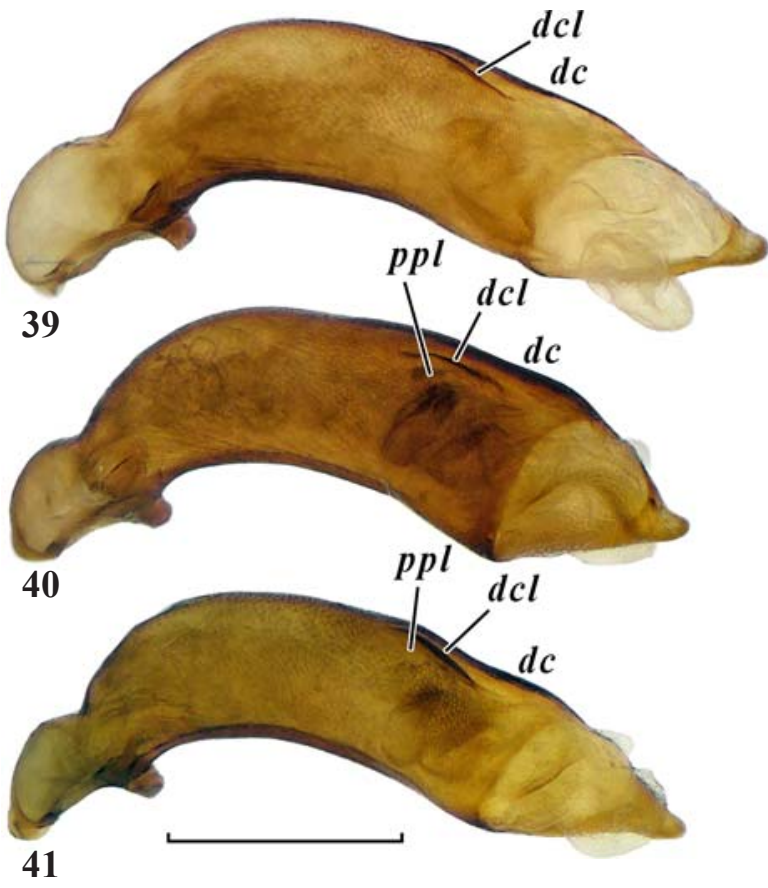

Figs 39-41. Median lobe of aedeagus, ventral aspect: 39 Amphimenes bidoupensis; $40-A$. gracilis; $41-A$. montanus; dc dorsal carina; $d c l$ - left dorsolateral carina; $p p l-1$ eft preapical protuberance. Scale bar: $0.5 \mathrm{~mm}$

Рис. 39-41. Средняя доля эдеагуса, слева: 39 - Amphimenes bidoupensis; 40 - A gracilis; 41 - A. montanus; dc - дорзальный киль; $d c l$ - левый дорзолатеральный киль; $p p l$ - левый предвершинный бугорок. Масштаб: 0,5 мм.
Everted and inflated internal sac (Figs 45-47) with $a$ on right side, $l r$ small, $d m$ very small and separate from $l r$; an additional, small, basal dorsomedial bulb $(d m b)$ present

DISTRIBUTION. Northern Vietnam (Thai Nguen, Cao Bang, Nghe An).

HABITATS AND HABITS. Under bark scales of live trees (Nghe An) and under bark of a dead tree (Cao Bang) in rainforests.

\subsection{Amphimenes (s. str.) montanus Fedorenko, 2010} Figs 41, 48-50.

Fedorenko, 2010: 23, 30 (env. Sa Pa, northern Vietnam).

MATERIAL. Type specimens and additional material as follows: $20 \sigma^{\top} \sigma^{\top}, 14$ 우 (SIEE, D. Fedorenko leg.), Northern Vietnam: Lao Cai, $40 \mathrm{~km}$ WNW of Lao Cai, env. Y Ty, Bat Xat National Park, $22^{\circ} 37^{\prime}-37.6^{\prime} \mathrm{N} 103^{\circ} 37.32-38.3^{\prime} \mathrm{E}, \mathrm{h}=1600-1900 \mathrm{~m}, 16-21 . X .2018$; $\sigma^{7}$, same data, except for $22^{\circ} 36^{\prime} 31^{\prime \prime} \mathrm{N} 103^{\circ} 37^{\prime} 23^{\prime \prime} \mathrm{E}, \mathrm{h}=2000-2100$ m, 4-14.VI.2019; $\sigma^{\prime \prime}$, same data except $22^{\circ} 36^{\prime} 02^{\prime \prime} \mathrm{N} 103^{\circ} 37^{\prime} 13^{\prime \prime} \mathrm{E}$ $\mathrm{h}=2200 \mathrm{~m} ; 50^{7} \mathrm{O}^{\prime}$, o, same data except $22^{\circ} 37^{\prime} 36^{\prime \prime} \mathrm{N} 103^{\circ} 37^{\prime} 32^{\prime \prime} \mathrm{E}$, $\mathrm{h}=1850 \mathrm{~m}$. Aedeagus examined in seven males.

DIAGNOSIS. Aedeagus (Figs 41, 48-50) similar to that of $A$. bidoupensis, except that $d c$ and $d c l$ are well-developed, higher and longer, $d c$ reaching apical orifice, dorsal groove deeper, and small $p p l$ present. Everted and inflated internal sac (Figs 48-50) with $a$ on right side; $l r$ large and long, much longer than wide at base; $d m$ vesicular and medium-sized.

DISTRIBUTION. This species is only known from Hoang Lien mountain ridge in northern Vietnam. The locality listed above is the second exact locality, next to Mt. Phang Xi Pang (= Fansipan).

HABITATS AND HABITS. Common under bark of standing dead trees in cloudy forests.

COMMENTS. Based on the material listed, the following additions and corrections to the species description are made: BL 6.2-7.6 mm. PW/PL 1.30-1.45 (1.37, n=5), 1.491.61 (1.54), PB/PA 1.43-1.53 (1.48), EL/EW 1.43-1.50 (1.48), EW/PW 1.42-1.55 (1.49), D1/EL 0.20-0.27 (0.23, $\mathrm{n}=5 \times 2)$, D2/EL 0.67-0.76 (0.72). Besides, the specimens listed share entirely pale legs, whereas the type specimens has the legs with femora infuscated. This, firstly, suggests the type specimens may only represent a local population or a high-montane form of the species and, secondly, reduces differences of the species from $A$. bidoupensis and A. gracilis to the following ones: the pronotum barely larger, $\mathrm{PW} / \mathrm{HW}$ 1.49-1.61 (vs. 1.34-1.50), with sides not or barely converging towards the base, the base broader relative to the apex, PB/PA 1.43-1.53 (vs. 1.31-1.43), and the reflexed lateral margin being basally wider than in the related species; the elytra are less square due to due to their narrower bases and both humeri and sides more rounded.

\subsection{Amphimenes (s. str.) ryukyuensis Habu, 1964}

Habu, 1964: 474, 475 (Ishigaki Is., Ryukius, Japan); 1967: 114, 116; 1982: 91; Fedorenko, 2010: 23. - carinacaulis Hunting et Yang, 2019: 10, 20 (Taiwan), syn.n.

MATERIAL. No specimen, except for digital images of the holotype of A. ryukyuensis at NIAES, Institute for Agro-Environmental Sciences, Tsukuba, Japan (http://www.naro.affrc.go.jp).

DISTRIBUTION. Southern Japan: Satsunans (Amamioshima Is. and Tokunoshima Is.), Ryukius (Iriomote Is. and Ishigaki Is.)

HABITATS AND HABITS. All specimens of A carinacaulis were hand collected in mixed forests at $640-1850 \mathrm{~m}$ elevations at night [Hunting, Yang, 2019].

COMMENTS. The above synonymy is based on the fact that A. carinacaulis has been described and, surprisingly, compared with the species of Amphimenes from Taiwan only, 
instead of with similar and closely related species outside the island. Of these, A. ryukyuensis is widespread in southern Japan, including Iriomote Is. and Ishigaki Is., these being much closer to Taiwan than to Satsunan Islands Amamioshima and Tokunoshima as other known localities of the species. I see no difference between the two species in body appearance and the shape of aedeagus. Accordingly I consider the two names as conspecific until evidence to the contrary.

\section{The medius species group.}

The group includes five apterous soil-dwelling species, two from southern Vietnam, two from Central Vietnam, and one from northern Vietnam. Elytral seta d1 inserted close to base is their main distinctive feature.

\subsection{Amphimenes (s. str.) acutipennis}

Fedorenko, sp.n.

Figs 6, 11-12, 31.

MATERIAL. Holotype $0^{7}$ (ZMMU): 'Vietnam, Kon Tum Province, Kon Plong Distr[ict]., $14^{\circ} 45^{\prime} \mathrm{N} / 108^{\circ} 18210^{\prime \prime} \mathrm{E}$, env. ngock Boc I Mt., h=1200-1300 m, 8-23.IV.2015, D.Fedorenko leg.'. Paratypes (ZISP, ZMMU, SIEE): $60^{7} \sigma^{\top}, 3$, 3 ,, same data; $\sigma^{\top},+$, same data except $14^{\circ} 44^{\prime} 20^{\prime \prime} \mathrm{N} / 108^{\circ} 19^{\prime} \mathrm{E}, \mathrm{h}=1100-1200 \mathrm{~m} ; 20^{\prime} 0^{\prime}$, 3우, same data, except for $14^{\circ} 45^{\prime} \mathrm{N} 108^{\circ} 17^{\prime} 51^{\prime \prime} \mathrm{E}, \mathrm{h}=1300-1400 \mathrm{~m}, 8-10 . \mathrm{VI} .2016$; $\sigma^{7},+$, , 'Vietnam, Gia Lai Province, $\sim 40 \mathrm{~km}$ ENE of Pleiku, $14^{\circ} 13^{\prime} 09^{\prime} \mathrm{N} /$ $108^{\circ} 19^{\prime} 48^{\prime}$ E, Kon Ka Kinh Nat[io]n[al]. Park, h=1470 m, 2130.V.2017, D.Fedorenko leg.'. Aedeagus examined in three males.

DESCRIPTION. Body apterous, large and slender (Fig. 6), BL 10.1-11.9 mm. Black; mouthparts, including labrum, anterior half to two thirds of clypeus, antennae, tarsi and trochanters red; lateral margins of elytra and extreme lateral margins of pronotum barely translucent with reddish-brown (more distinctly translucent under spotlight). Sometimes antennomeres 3 and 4 infuscated. Microsculpture isodiametric, distinct yet slightly superficial on head, very coarse, granulate-aciculate over pronotum. Elytra with transverse, mostly moderately transverse, microsculpture becoming isodiametric on explanate lateral margins. As a result, head and elytra moderately shiny, much shinier than dull pronotum. Elytral cross-striated sculpture dense and conspicuous in basal half, becoming increasingly weak and sparse apicad until nearly indistinct before apex.

Head: eyes slightly flattened, twice as long as genae, these smoothly extended into neck. Posterior supra-ocular seta clearly behind posterior margin of eye (about $1 / 6$ eye length distant from eye). Antennae very long, surpassing base of pronotum by about apical 4.5 antennomeres.

Pronotum subcordate, broadest at anterolateral seta a fourth from apex, only a fifth wider than long, PW/PL 1.18-1.23 (mean 1.20, n=5), PW/HW 1.45-1.48 (1.47). Base a third broader than apex, PB/PA 1.28-1.37 (1.34), straight medially, with lateral lobes evenly convex caudad, half as wide as and slightly produced beyond median part. Basal angles highly obtuse yet mostly distinct. Apex deeply sinuate; apical angles porrect, slightly acute and sharp. Sides evenly rounded in apical two thirds, gently sinuate behind. Disc slightly convex, with fine and dense transverse wrinkles. Lateral margins rather strongly reflexed, narrow anteriorly, moderately wide in basal half; lateral grooves fairly wide and more or less flat at bottom. Median line entire and moderately deep; basal transverse impression well defined, angulate or convex forward. Basal
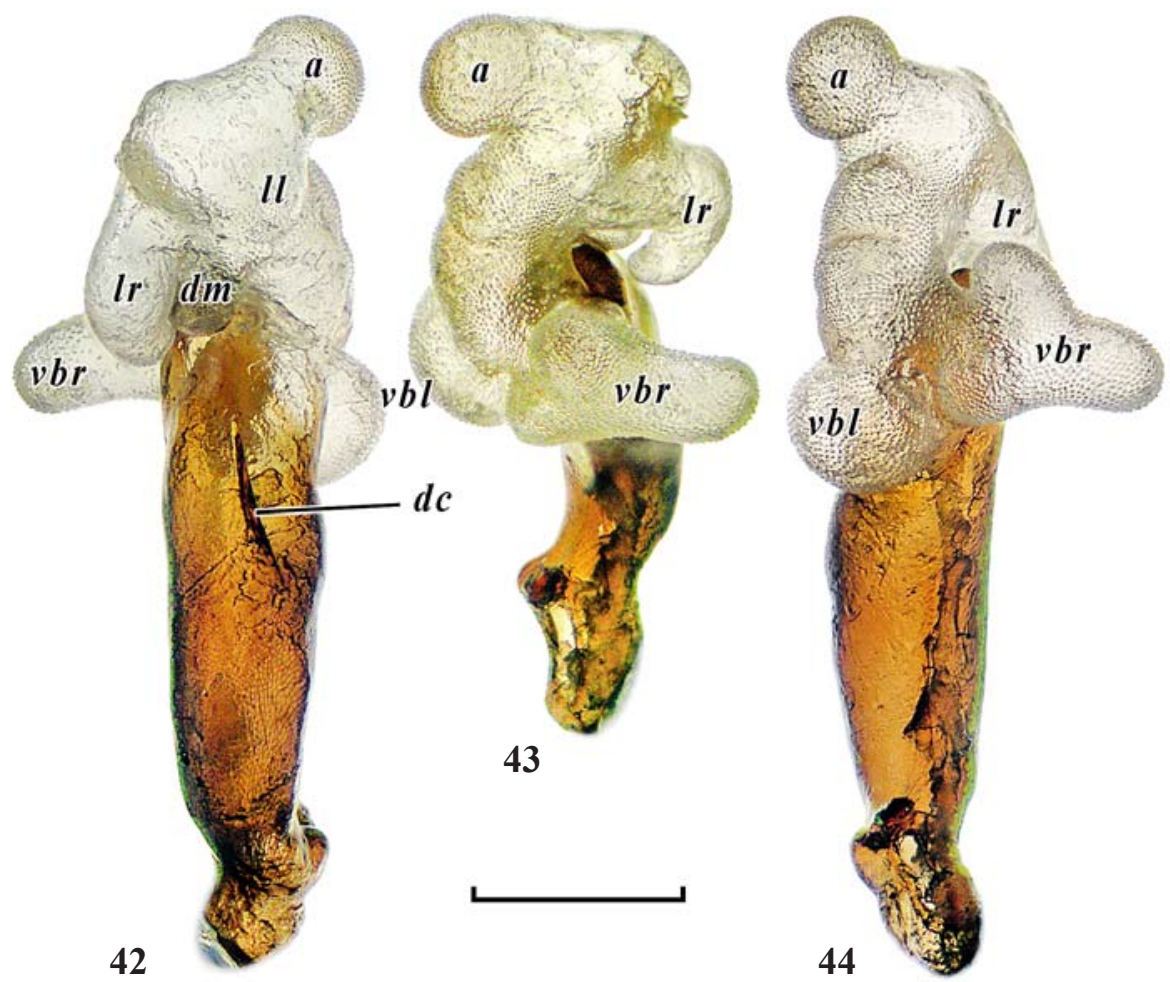

Figs 42-44. Amphimenes bidoupensis, median lobe of aedeagus, with internal sac everted and inflated: 42 - dorsal aspect; 43 — ventroapical aspect; 44 - ventral aspect; $d c$ — dorsal carina; bulbs: $a$ — apical; $d m$ - dorsomedial; $l l$ — lateral left; $l r$ — lateral right; $v b l$ ventrobasal left; $v b r$ - ventrobasal right. Scale bar: $0.5 \mathrm{~mm}$.

Рис. 42-44. Amphimenes bidoupensis, средняя доля эдеагуса с вывернутым и надутым эндофаллусом: 42 - дорзально; $43-$ вентроапикально; 44 - вентрально; $d c$ - дорзальный киль; пузыри: $a$ - апикальный; $d m$ — дорзомедиальный; $l l$ - боковой левый; $l r$ - боковой правый; $v b l$ - вентробазальный левый; $v b r$ - вентробазальный правый. Масштаб: 0,5 мм. 
foveae deep, round, merged into reflexed lateral margin and thence fairly wide; each as a very shallow yet fairly wide groove reaching middle or just apical margin. Paramedian foveae as small and very shallow to indistinct pits or short longitudinal impressions a third from apex and equidistant from median line and lateral groove.

Elytra elliptic, EL/EW 1.41-1.61 (1.53), EW/PW 1.40 1.52 (1.44), oblique from mesothoracic peduncle, with humeri rounded off, evenly rounded on sides, broadest at middle. Apical truncature oblique, deeply sinuate, more so close to acute and pointed posterolateral angles. Apices rectangular combined, with extreme tips slightly separate and sharp to blunt. Lateral margin very widely explanate behind the level of seta $\mathrm{d} 1$ and flat in horizontal plane. Striae deep; intervals convex. Interval 3 with three setae, D1/EL 0.16-0.18 (0.17, $\mathrm{n}=5 \times 2)$, D2/EL 0.63-0.72 (0.67), D3/EL 0.91-0.94 (0.93).

Metepisternum 1.03-1.04 times as long as wide.

Tarsomere 5 with two pairs of ventral setae. Male profemur without tubercle, mesotrochanter with a small tubercle; mesotibia 5-tuberculate along inner margin.

Aedeagus (Figs 11-12, 31): as in A. giganteus, except that median lobe in lateral view is much broader medially than just behind basal bulb (vs. subequally wide), with apex in ventral view being slightly more curved to the left.

DIAGNOSIS. The largest species within the genus. It is similar to A. giganteus, except that that is smaller, with elytral base convex forward and outer angles obtuse and apically rounded, etc.

DISTRIBUTION. Known from two fairly close localities in central Vietnam (Gia Lai, Kon Tum).

NAME. Refers to acute posterolateral angles of the elytra.

HABITATS AND HABITS. This species occurs on the underside of logs and smaller tree fragments on the ground in monsoon forests at 1100-1470 m altitude. It lives syntopically with $A$. konplongensis sp.n. and/or A. basipunctatus sp.n.

\subsection{Amphimenes (s. str.) basipunctatus Fedorenko, sp.n. \\ Figs 7, 17-18, 33}

MATERIAL. Holotype $\sigma^{7}$ (ZMMU): 'Vietnam, Kon Tum Prov[ince]., Chu Mom Ray National Park, $14^{\circ} 30$ N $/ 107^{\circ} 42^{\prime} 30^{\prime \prime} \mathrm{E}$ ngock To Lum mt., $\mathrm{h}=1100-1350 \mathrm{~m}$ 28.III-4.IV.2015, D.Fedorenko leg.'. Paratypes (ZISP, ZMMU, SIEE), $70^{7} 0^{7}$, 6우, same data; 9 (SIEE), Vietnam, Kon Tum Province, Kon Plong Distr., $14^{\circ} 45^{\prime} \mathrm{N} /$ $108^{\circ} 17^{\prime} 51^{\prime \prime} \mathrm{E}$, env. ngock Boc $1 \mathrm{Mt}$., $\mathrm{h}=1300-1400 \mathrm{~m}, 8-10 . \mathrm{VI} .2016$, D.Fedorenko leg.; $20^{7} \sigma^{\top}$, 2 2 +, , 'Vietnam, Gia Lai Province, $40 \mathrm{~km}$ ENE of Pleiku, $14^{\circ} 13^{\prime} 09^{\prime \prime} \mathrm{N} / 108^{\circ} 19^{\prime} 48^{\prime \prime} \mathrm{E}$, Kon Ka Kinh Nat[io]n[al]. Park, h=1470 m, 21-30.V.2017, D.Fedorenko leg.'; ○", data except $14^{\circ} 13^{\prime} 40^{\prime \prime} \mathrm{N} / 108^{\circ} 18^{\prime} 35^{\prime \prime} \mathrm{E}, \mathrm{h}=1300-1380 \mathrm{~m}$; $\sigma^{\prime}$, 'Vietnam, Quang Nam Prov., Nam Gian Distr., Song Thanh Natn. Park, $15^{\circ} 32^{\prime} 51^{\prime \prime} \mathrm{N} / 107^{\circ} 23^{\prime} \mathrm{E}, \mathrm{h}=1230 \mathrm{~m}, 23 . \mathrm{IV}-11 . \mathrm{V} .2019$, leg. D.Fedorenko'; $30^{7} 0^{7}$, o , same data, except for either $15^{\circ} 34^{\prime} 07^{\prime \prime} \mathrm{N} /$ $107^{\circ} 23^{\prime} 13^{\prime \prime} \mathrm{E}, \mathrm{h}=1010 \mathrm{~m}$; or $15^{\circ} 32-33^{\prime} \mathrm{N}, 103^{\circ} 22^{2}-23^{\prime} \mathrm{E}, \mathrm{h}=1100$ $1230 \mathrm{~m}$; or $15^{\circ} 33^{\prime} 48^{\prime \prime} \mathrm{N} / 107^{\circ} 23^{\prime} 22^{\prime \prime} \mathrm{E}, \mathrm{h}=1050 \mathrm{~m}$; or $15^{\circ} 33^{\prime} 19^{\prime \prime} \mathrm{N} /$ $107^{\circ} 23^{\prime} 29^{\prime \prime} \mathrm{E}, \mathrm{h}=1070 \mathrm{~m}$. Aedeagus examined in eight males.

DESCRIPTION. As for A. acutipennis sp.n. except as follows: Body (Fig. 7) medium-sized, BL 6.7-8.7 mm. Black yet barely paler than $A$. acutipennis; antennae entirely pale, tibiae and tarsi red or pale brown, or tibiae slightly darker than tarsi while distinctly paler than femora. Lateral margin of elytra more clearly translucent with reddish-yellow. Microsculpture coarse, isodiametric on head, granulate-aciculate on pronotum, much more superficial on elytra, consisting of very transverse meshes mixed with wider transverse meshes here and there; explanate lateral margin of elytra with isodiametric microsculpture. Head and pronotum subequally dull, elytra moderately shiny.
Antennae surpassing pronotal base by apical 3-3.5 antennomeres.

Pronotum cordate, much narrower relative to elytra, $\mathrm{PW} /$ PL 1.16-1.21 (mean 1.18, n=5), PW/HW 1.42-1.50 (1.47). Base straight or indistinctly convex posteriad, on a level with gently rounded lateral lobes or barely produced, $\mathrm{PB} / \mathrm{PA}$ $1.33-1.43$ (1.38). Basal angles slightly to very obtuse. Basal foveae rather small and mostly not extended apicad. Paramedian foveae usually indistinct, situated midway between median line and narrow lateral grooves. Reflexed lateral margin slightly to moderately reflexed, narrow from apical angle to anterolateral seta, slightly and increasingly wider toward basal angles.

Elytra: EL/EW 1.41-1.47 (1.44), EW/PW 1.55-1.69 (1.59); base very narrow yet distinct; posterolateral angles very obtuse and rounded; apices obtuse and pointed combined. Apical truncature barely sinuate, more deeply near apex. Reflexed lateral margin slightly concave dorsally, wide medially, much narrower before and behind. Intervals convex, inner ones slightly convex to nearly flat. Interval 3 with three setae; d1 very close to base, D1/EL 0.09-0.12 (0.11, $\mathrm{n}=5 \times 2)$, D2/EL 0.60-0.69 (0.66), D3/EL 0.89-0.93 (0.92).

Metepisternum short, ES3L/ES3W 0.85-1.0 (0.92, $\mathrm{n}=3)$.

In male, profemur without tubercle, mesotrochanter with a small tubercle, mesotibia with four tubercles along inner margin.

Aedeagus (Figs 17-18, 33): as in the previous species, except for apical lamella slenderer and nearly straight in ventral view.

DIAGNOSIS. This species is transitional from A. medius and $A$. tonkinensis sp.n. to A. giganteus and $A$. acutipennis sp.n. in size. The three species of this group, that share similar elytral chetome, A. basipunctatus sp.n., A. giganteus, and $A$. acutipennis sp.n., have distinctive elytral apices each. The apices are either contiguous and sharp, with indistinct sinuation outside, in A. basipunctatus sp.n. or slightly separate at sutural angle, with the apical truncature either deeply and evenly concave (A. giganteus) or very deeply concave just behind outer angle (A. acutipennis sp.n.). For other differences see the key.

VARIATION. Specimens from the northern population (Quang Nam) may be barely larger than those from southern ones, BL being 7.3-8.7 or $6.7-8.1 \mathrm{~mm}$, respectively.

DISTRIBUTION. Central Vietnam (Gia Lai, Kon Tum).

NAME. Refers to the anterior discal seta (d1) inserted closer to elytral base than in the congeners.

HABITATS AND HABITS. As for the previous species.

\subsection{Amphimenes (s. str.) tonkinensis Fedorenko, sp.n.}

Fig. 8 .

MATERIAL. Holotype + (ZMMU): 'N-Vietnam, $40 \mathrm{~km}$ WNW of Lao Cai, env. Y Ty, Bat Xat N[ational]P[ark], 22 $2^{\circ} 36^{\prime} 02^{\prime \prime} \mathrm{N} /$ $103^{\circ} 37^{\prime} 13^{\prime \prime} \mathrm{E}, \mathrm{h}=2200 \mathrm{~m}, 4-14 . \mathrm{VI} .2019$, leg. D.Fedorenko'

DESCRIPTION. Body apterous, small (Fig. 8), BL 6 $\mathrm{mm}$, shiny black, with pronotum dull. Clypeus, except for brownish base, labrum, mouthparts, antennae, legs, gula, prosternum, hypomera, meso- and metaventrite, and abdominal sternite III between metacoxae red; abdomen widely reddish along middle, underside otherwise rather dark brown; reflexed lateral margins of elytra translucent with red, those of pronotum translucent with reddish-brown. Microsculpture isodiametric on head; pronotal microsculpture very coarse, granulate-aciculate in basal half and along sides, otherwise consisting of isodiametric or barely transverse meshes. Elytra with meshed microsculpture superficial, isodiametric or barely 
transverse. Elytral cross-striated sculpture vestigial, hardly traceable along middle of elytral intervals basally, nearly indistinct behind.

Head narrow, with eyes rather flat and small, as long as genae which almost smoothly extend into neck. Posterior supra-ocular seta distant far from posterior margin of eye. Antennae fairly short, surpassing base of pronotum by apical antennomere.

Pronotum narrow, subcordate, nearly square, broadest at anterolateral seta slightly less than a third $(0.30)$ from apex, slightly wider than long, PW/PL 1.16, PW/HW 1.39. Base a fourth broader than apex, PB/PA 1.24, barely concave between lateral lobes; these convex caudad and more rounded laterally. Basal angles very obtuse and blunt. Apex deeply sinuate; apical angles porrect and acute. Sides evenly rounded in apical three fourths, gently sinuate behind. Disc flattened. Lateral margins together with basal angles and laterobasal lobes strongly reflexed, slightly wider before than behind. Median line entire and moderately deep; basal transverse impression short and deep. Basal foveae short and deep, each extended apicad into a very shallow impression that disappears medially. Paramedian foveae indistinct.

Elytra elliptic, EL/EW 1.45, EW/PW 1.71, broadest medially, with common base narrow, humeri round yet traceable, and sides evenly rounded up to rounded posterolateral angles. Apical truncature oblique, slightly sinuate. Apices very slightly obtuse combined and nearly contiguous. Lateral margin rather widely explanate in inner three fifths. Striae deep, intervals slightly convex, almost flat on disc. Interval 3 with three setae, D1/EL 0.13, D2/EL 0.37/0.40, D3/EL 0.90/ $0.91(0.93)$.

Metepisternum short, about as long as wide.

Tarsomere 5 with one pair of ventral setae, preapical.

DIAGNOSIS. Within the medius-group, this species is easily recognizable by the combination of the body small, with narrow forebody and pale appendages, nearly isodiametric elytral microsculpture, three elytral discal setae present, with seta $\mathrm{d} 1$ inserted before middle.

DISTRIBUTION. Known from the type locality only, that is on the Hoang Lien Mt. Ridge, Lao Cai, northern Vietnam.

NAME. Toponymic; refers to the former historical name of northern Vietnam.

HABITATS AND HABITS. The only female specimen was hand collected under a small tree fragment on the ground in a cloudy forest. The species appears to live syntopically with $A$. reflexicollis.

COMMENTS. Two elytral characters, nearly isodiametric microsculpture and seta d1 inserted distinctly before middle, are not characteristic of the other members of the medius-group and the species range is distinctive. Accordingly this species may require to be placed in the separate group of itself.

The planicollis species group.

The group includes four apterous soil-dwelling species, three from northern Vietnam and one from Central Vietnam. The group is defined by the combination of the elytral seta $\mathrm{d} 1$ missing and seta $\mathrm{d} 2$ situated behind middle.

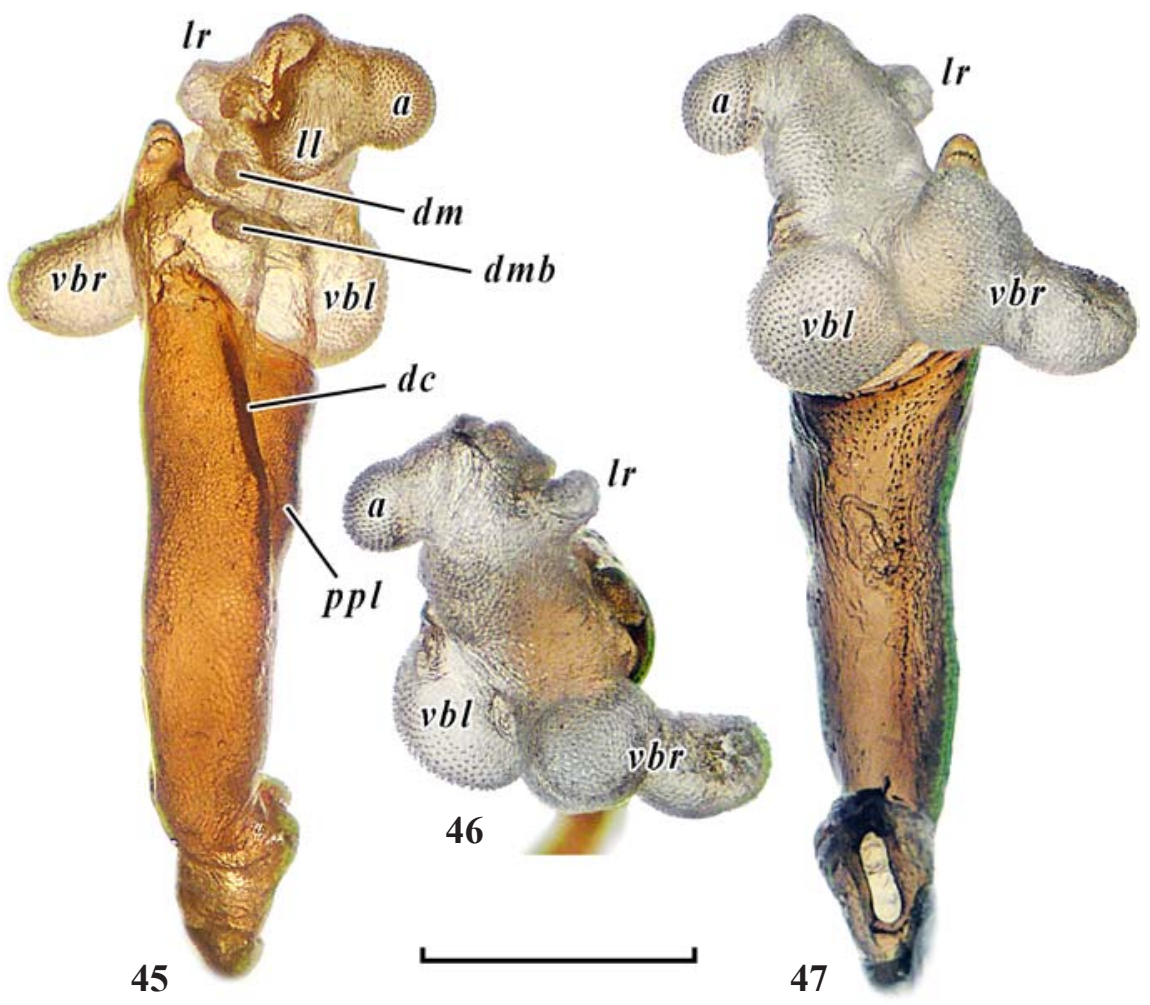

Figs 45-47. Amphimenes gracilis, median lobe of aedeagus, with internal sac everted and inflated: 45 — dorsal aspect; 46 — ventroapical aspect; 47 - ventral aspect; $d m b$ - dorsomedial basal bulb; $p p l$ - left preapical protuberance. The other symbols and scale bar as in Figs 42-44.

Рис. 45-47. Amphimenes gracilis, средняя доля эдеагуса с вывернутым и надутым эндофаллусом: 45 - дорзально; 46 вентроапикально; 47 — вентрально; $d m b$ — дорзомедиальный базальный пузырь; $p p l$ - левый предвершинный бугорок. Прочие условные обозначения и масштаб как на рис. 42-44. 


\subsection{Amphimenes (s. str.) konplongensis} Fedorenko, sp.n.

Figs 9, 21-22, 38.

MATERIAL. Holotype $\sigma^{\prime}$ (ZMMU) labelled: 'Vietnam, Kon Tum Province, Kon Plong Distr[ict]., $14^{\circ} 45^{\prime}$ N/ $108^{\circ} 18^{\prime} 10^{\prime \prime E}$, env. ngock Boc I Mt., h =1200-1300 m, 8-23.IV.2015, D.Fedorenko leg.'. Paratypes (SIEE, ZISP, ZMMU): $60^{7} \sigma^{7}, 3$, $9+9$, same data; $\sigma^{7}$,,+ , same data, except for $14^{\circ} 44^{\prime} 20^{\prime} \mathrm{N} / 108^{\circ} 19^{\prime} \mathrm{E}, \mathrm{h}=1100-1200 \mathrm{~m} ; 50^{\top} \mathrm{O}^{\top}$, 2 우, same data, except for $14^{\circ} 45^{\prime} \mathrm{N} / 108^{\circ} 17^{\prime} 51^{\prime \prime} \mathrm{E}, \mathrm{h}=1300-1400 \mathrm{~m}$, 8-10.VI.2016; +, 'Vietnam, Quang Nam Prov., Nam Gian Distr., Song Thanh Natn. Park, $15^{\circ} 32^{\prime} 51^{\prime \prime N} / 107^{\circ} 23^{\prime} \mathrm{E}, \mathrm{h}=1230 \mathrm{~m}$, 23.IV11.V.2019, leg. D.Fedorenko'. Aedeagus examined in three males.

DESCRIPTION. Body (Fig. 9) apterous, medium-sized for the genus, BL 6-7.1 mm, and black. Mouthparts, including labrum, antennae, trochanters, tibiae, tarsi and femoral apices reddish-yellow; femora otherwise dark brown to brownblack; lateral margins of elytra and narrow lateral margins of pronotum barely to distinctly translucent with red. Microsculpture coarse, isodiametric on head, granulate at middle of pronotum, granulate-aciculate around; elytral microsculpture much more superficial yet distinct, consisting of moderately to very transverse meshes becoming isodiametric ones on explanate lateral margin. Head and pronotum equally dull, slightly shining, elytra shinier. Elytral intervals moderately densely cross-striated, less so behind.

Head: eyes slightly flattened; genae about a third as long as eyes, mostly very smoothly extended into neck. Posterior supra-ocular seta just behind posterior margin of eye. Antennae long, surpassing pronotal base by about apical three antennomeres.

Pronotum cordate, broadest slightly less than two fifths from apex, a third to two fifths wider than long, PW/PL

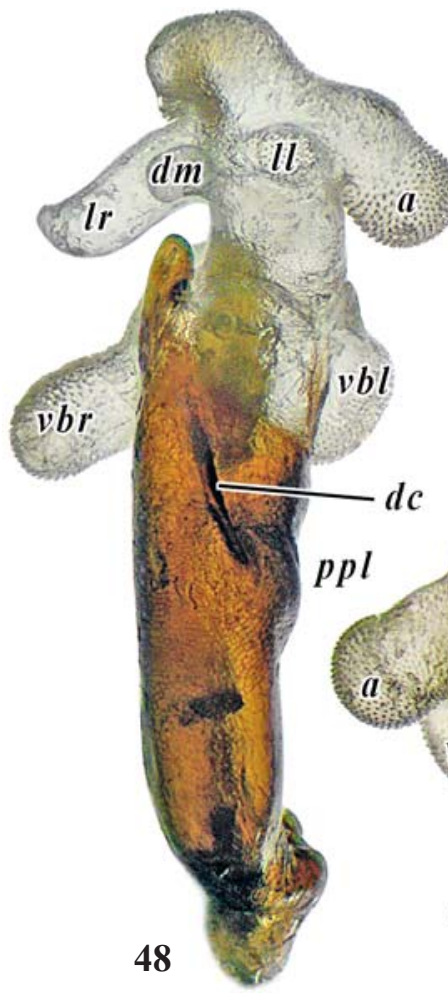

1.34-1.40 (mean 1.37, n=5), PW/HW 1.47-1.60 (1.51). Base two fifths wider than apex, PB/PA 1.40-1.44 (1.42), with median part on a level with and a third wider than lateral lobes, all slightly rounded or the lobes more rounded toward basal angles. Basal angles slightly to highly obtuse. Apex deeply sinuate; apical angles porrect, slightly acute, and blunt. Sides evenly rounded in apical four fifths, mostly distinctly sinuate behind and barely diverging basad. Disc moderately convex, very finely transversely rugulose. Lateral margins moderately explanate-reflexed, narrow apically and gradually broadening to rather wide at basal angles; lateral groove narrow. Median line moderately deep and mostly obsolete behind well defined basal transverse impression. Basal foveae round and moderately deep, not extended forward. Paramedian foveae usually wide yet very shallow to indistinct.

Elytra broadly oval, EL/EW 1.39-1.48 (1.44), EW/PW $1.45-1.56(1.49)$, at base as wide as pronotal base, evenly rounded on sides, broadest at middle, with humeri distinct yet widely rounded and posterolateral angles very obtuse and rounded; apices contiguous, subrectangular to obtuse combined, sharp or slightly blunted. Apical truncature oblique, slightly sinuate near apex. Striae deep; intervals moderately convex, outer ones slightly convex to nearly flat. Interval 3 with two setae, D2/EL 0.58-0.63 $(0.60, \mathrm{n}=5 \times 2)$, D3/EL 0.92-0.94 (0.93)

Metepisternum short, ES3L/ES3W 0.84-0.90 (0.87, n=3).

Tarsomere 5 with one pair of ventral setae, metatarsomere often with additional vestigial pair of setae proximal to normal setae. In male, profemur without tubercle, mesotrochanter with a small tubercle; mesotibia with three or four minute tubercles along inner margin. 
Aedeagus median lobe cylindrical (Figs 21-22, 38).

DIAGNOSIS. For details see the key.

DISTRIBUTION. Known from the type locality only.

NAME. Given after the provenance of the species, Kon Plong District, Kon Tum, Vietnam.

HABITATS AND HABITS. As for A. acutipennis sp.n.

\subsection{Amphimenes (s. str.) bicoloripes Fedorenko, sp.n.} Figs 23-24, 27.

MATERIAL. Holotype $\sigma^{\prime}$ (ZMMU) labelled: 'N-Vietnam, Nghe An Prov., Que Phong Distr., Pu Hoat National Park, 1946'35'N/ $104^{\circ} 48^{\prime} 13^{\prime \prime} \mathrm{E}, \mathrm{h}=1350 \mathrm{~m}$ 15-27.V.2019, leg. D.Fedorenko'. Paratypes (SIEE) $80^{7} \sigma^{7}, 12 \circ 0$, same data; $5 \sigma^{7} \sigma^{7}, 4$, + , same data, except $19^{\circ} 45^{\prime} \mathrm{N} / 104^{\circ} 46^{\prime} 38^{\prime \prime} \mathrm{E}, \mathrm{h}=1220 \mathrm{~m}$; ㅇ, same data, except $19^{\circ} 46^{\prime} 13^{\prime \prime} \mathrm{N} /$ $104^{\circ} 47^{\prime} 08^{\prime \prime} \mathrm{E}, \mathrm{h}=1030 \mathrm{~m}$. Aedeagus examined in eight males.

DESCRIPTION. As for A. konplongensis, except for small differences that concern body proportions, elytral microsculpture, and shape of aedeagus. Body of nearly the same facies as in A. konplongensis (see Fig. 9), BL 5.8-7.5 mm. elytral microsculpture consisting of dense transverse lines to extremely narrow and almost indistinct transverse meshes. Pronotum slightly narrower, PW/PL 1.24-1.35 (mean 1.29, $\mathrm{n}=7)$, PW/HW 1.44-1.54 (1.48), PB/PA 1.34-1.41 (1.36). Elytra broadly oval, EL/EW 1.41-1.50 (1.45), EW/PW 1.491.60 (1.57). D2/EL 0.66-0.72 (0.69, $\mathrm{n}=6 \times 2), 0.56 / 0.59$ in one specimen measured, D3/EL 0.91-0.94 (0.93).

Tarsomere 5 with two pairs of ventral setae; mesotibia with four tubercles along inner margin.

Aedeagus (Figs 23-24, 27) with median lobe strongly twisted; left margin angulate at middle.

DIAGNOSIS. For details see the key.

DISTRIBUTION. Known from the type locality only.

NAME. Refers to the bicoloured legs, pale, with femora infuscated.

HABITATS AND HABITS. Under various tree fragments on the ground in monsoon forests, mostly above 1200 $\mathrm{m}$ elevation.

\subsection{Amphimenes (s. str.) reflexicollis Fedorenko, 2010}

Fedorenko, 2010: 39 (Tam Dao, northern Vietnam).

MATERIAL. Northern Vietnam (SIEE; D. Fedorenko leg.) $4 \sigma^{\top} \sigma^{\top}, 3$, 9 , Cao Bang, $40 \mathrm{~km}$ W of Cao Bang, Phia Oac — Phia Den Nat. Park, Phia Oac Mt, 22 $36^{\prime} 03^{\prime \prime N} 105^{\circ} 53^{\prime} 07^{\prime \prime} \mathrm{E}, \mathrm{h}=1300 \mathrm{~m}, 3-$ 11.X.2018; o (SIEE), same data, except for $22^{\circ} 36^{\prime} 25^{\prime \prime} \mathrm{N}$ $105^{\circ} 52^{\prime} 08^{\prime \prime} \mathrm{E}, \mathrm{h}=1650-1700 \mathrm{~m} ; 50^{7} \mathrm{\sigma}^{\top}$, 4우, same data, except for $22^{\circ} 36^{\prime} 30^{\prime \prime} \mathrm{N} 105^{\circ} 52^{\prime} 20^{\prime \prime} \mathrm{E}, \mathrm{h}=1600-1650 \mathrm{~m}$; 9 $0^{\top} \mathrm{o}^{\top}, 3+00$, Lao Cai, $40 \mathrm{~km}$ WNW of Lao Cai, env. Y Ty, Bat Xat Nat. Park, $22^{\circ} 372-$ $37.6^{\prime} \mathrm{N} 103^{\circ} 37.32-38.3^{\prime} \mathrm{E}, \mathrm{h}=1600-1900 \mathrm{~m}, 16-21 . X .2018 ; 50^{7} \mathrm{O}^{7}$, 5 우, same data, except for $22^{\circ} 36^{\prime} 31^{\prime \prime} \mathrm{N} 103^{\circ} 37^{\prime} 23^{\prime \prime} \mathrm{E}, \mathrm{h}=2000-2100$ m, 4-14.VI.2019; $100^{7} \sigma^{7}$, 5오, same data except $22^{\circ} 37^{\prime} 36^{\prime \prime} \mathrm{N}$ $103^{\circ} 37^{\prime} 32^{\prime \prime} \mathrm{E}, \mathrm{h}=1850 \mathrm{~m}$. Aedeagus examined in seven males.

REDESCRIPTION. Based on material listed, the following additions are only necessary: BL 7.6-9.3 mm. PW/PL $1.31-1.42$ (1.35, $\mathrm{n}=10), \mathrm{PW} / \mathrm{HW} 1.50-1.68$ (1.59), PB/PA 1.41-1.52 (1.47), EL/EW 1.43-1.51 (1.48), EW/PW 1.45$1.56(1.51)$, D2/EL 0.61-0.71 (0.67, n=9×2).

DISTRIBUTION. The species range covers montane areas of northern Vietnam from Lao Cai Province in the west to Vinh Phuc (type locality) and Cao Bang provinces in the east.

HABITATS AND HABITS. This species occurs under smaller tree fragments on the ground. Individual adults were taken under bark of standing dead trees up to 1-2 $\mathrm{m}$ above ground.

COMMENTS. There are some subtle differences between two populations of the species, western ( $\mathrm{LaO}$ Cai) and eastern (Cao Bang). The adults from the former have the pronotum barely larger, PW/HW 1.54-1.68 (1.61) vs. $1.50-$ 1.61 (1.56), EW/PW 1.45-1.52 (1.48) vs. 1.49-1.56 (1.54), with base wider, PB/PA 1.47-1.52 (1.49) vs. 1.41-1.49 (1.45); explanate and reflexed lateral margin barely wider, sides indistinctly sinuate to subconvex ( $v s$. subsinuate to straight), and basal angles subrectangular to obtuse (vs. nearly right with narrowly rounded apices); and USS continuous and consisting of 16-18 US (vs. 15-17).

\section{The brunneus species group.}

The group includes five apterous soil-dwelling species from northern Vietnam; they all share elytral seta d1 missing and seta $\mathrm{d} 2$ situated before middle, combined with elytral cross-striated sculpture strongly reduced to nearly indistinct in most species. Three species of the group are known based on female holotypes only.

\subsection{Amphimenes (s. str.) femoralis Fedorenko, sp.n.} Figs 10, 19-20, 35.

MATERIAL. Holotype + (ZMMU) and paratypes $\sigma^{\top}, 4 \circ 9$ (SIEE), labelled: 'N[orthern]-Vietnam, $40 \mathrm{~km} \mathrm{~W}$ of Cao Bang, Phia Oac Mt., $22^{\circ} 36^{\prime} 25^{\prime \prime} \mathrm{N} / 105^{\circ} 52^{\prime} 08^{\prime \prime} \mathrm{E}, \mathrm{h} \sim 1650-1700 \mathrm{~m}$, deciduous forest, 3-11.X.2018, leg.D.Fedorenko'.

DESCRIPTION. Body (Fig. 10) apterous, small, BL 6.2$6.7 \mathrm{~mm}$, and shiny black. Head and pronotum slightly dull, sometimes indistinctly paler; clypeus entirely or in apical half, labrum, mouthparts, antennae, and legs reddish-yellow; femora infuscated except apically. Pronotal lateral margin barely translucent with brown red, reflexed lateral margins of elytra narrowly red, becoming reddish brown just inside. Microsculpture coarse, isodiametric on head and at middle of pronotum, nearly granulate around; elytral microsculpture very superficial, consisting of very transverse meshes that become isodiametric ones on explanate lateral margin. Elytral cross-striated sculpture vestigial, hardly traceable in basal $1 / 2-1 / 3$, slightly more distinct close to base.

Head with slightly flattened eyes; genae about half as long as eyes. Posterior supra-ocular seta about $2 / 5$ eye length distant from posterior margin of eye. Antennae surpassing pronotal base by about apical two antennomeres.

Pronotum cordate, broadest slightly more than a third from apex, less than a third wider than long, PW/PL 1.28$1.31(1.29, \mathrm{n}=6)$, and half wider than head, PW/HW 1.481.55 (1.51). Base a third wider than apex, PB/PA 1.29-1.39 (1.34), with median part about as wide as lateral lobes; these evenly rounded and slightly projecting, more rounded towards highly obtuse basal angles. Apex very deeply sinuate; apical angles porrect, slightly acute and blunt. Sides rounded, more so toward apical angles, distinctly sinuate before basal ones. Disc convex, explanate lateral margins strongly reflexed, very narrow before anterolateral seta, moderately and increasingly wide behind. Median line deep, reaching apex and not quite reaching base. Basal foveae rather small, round, deeper just in front of meeting point of basal median part and lateral lobes. Basal transverse impression deep. Paramedian foveae small, moderately deep to indistinct, situated about midway between median line and lateral margin $2 / 5$ from apex.

Elytra broadly oval, a third longer than wide, EL/EW 1.31-1.41 (1.34), and two thirds wider than pronotum, EW/ PW 1.59-1.68 (1.66), broadest at middle, with evenly rounded sides. Humeri distinct yet more or less widely rounded, posterolateral angles very obtuse and blunt. Apical truncature oblique and rather transverse, barely sinuate; apices mostly very obtuse combined and blunt. Striae deep; intervals convex basally and in apical fourth, slightly less convex to nearly 
flat in between. Interval 3 bisetose, D2/EL 0.42-0.55 (0.49, $\mathrm{n}=6 \times 2$ ), posterior discal seta close to apex.

Metepisternum short: ES3L/ES3W 0.86-0.89 ( $\mathrm{n}=2)$.

Tarsomere 5 with one pair of ventral setae. In male, profemur a third from base with a large ventral tubercle; mesotibia 4-tuberculate along apical 2/5 inner margin.

Aedeagus median lobe (Figs 19-20, 35) slightly twisted and dilated before apical orifice because a conspicuous left ventrolateral bulge is present.

DIAGNOSIS. This species belongs to the brunneusgroup that includes totally five species, being very similar to A. brunneus and A. kabakovi. The latter two species share unicoloured pale legs, being distinctive also in having either a weaker microsculpture on the head and pronotum ( $A$. kabakovi) or the body smaller, with elytral apices more pointed combined, subrectangular (A. brunneus) vs. very obtuse. Differences between the three species in body proportions are subtle, yet not overlapped (Table).

DISTRIBUTION. Known from the type locality only.

NAME. Refers to the femora infuscated.
Acknowledgements. I am very indebted to Dr. Beulah Garner (BMNH) and Dr. Kirill Makarov (MPSU) for loan of material under their care, and to Dr. Alexei Polilov and Mr. Igor Melnik (both from Moscow) for donating specimens. This study was funded by the Presidium of the Russian academy of sciences, Program No.41 "Biodiversity of natural systems and biological resources of Russiaâ".

\section{References}

Andrewes H.E. 1931. Papers on Oriental Carabidae.-XXV // Ann. \& Mag. Nat. Hist. Ser.10. Vol.7. P.513-528.

Aston P. 2016. Catalogue and bibliography of the Hong Kong Carabidae Latreille, 1802 (Coleoptera: Adephaga), with notes on the historic boundaries of Hong kong as related to zoological collections // Zootaxa. Vol.4121. No.3. P.201-257.

Table. Selected ratios in three Amphimenes species. Таблица. Пропорции тела трёх видов Amphimenes.

\begin{tabular}{l|c|c|c|c|c|c|c|c}
\hline \multicolumn{1}{c|}{ Species } & $\mathbf{n}$ & $\mathbf{B L}, \mathbf{m m}$ & $\mathbf{P W} / \mathbf{H W}$ & mean & PW/PL & mean & PB/PA & mean \\
\hline A. brunneus & 1 & 5.7 & 1.38 & 1.38 & 1.32 & 1.32 & 1.26 & 1.26 \\
A. kabakovi & 1 & 6.3 & 1.46 & 1.46 & 1.34 & 1.34 & 1.25 & 1.25 \\
A. femoralis sp.n. & 6 & $6.2-6.7$ & $1.48-1.55$ & 1.51 & $1.28-1.31$ & 1.29 & $1.29-1.39$ & 1.34 \\
\hline
\end{tabular}

HABITATS AND HABITS. An apterous soil-dwelling species occurring under smaller tree fragments on the ground and sharing these habitats with the sympatric species $A$. reflexicollis.

COMMENTS. Relationships between A. brunneus, A. kabakovi and $A$. femoralis sp.n. are obscured by their great similarity and the males unknown for the former two. More material is required to clarify whether they are species or subspecies, or conspecific.

\section{The brunneus species group.}

This group includes two species, one apterous soil-dwelling from southern Vietnam, the other macropterous arboricolous and widespread. Both share the body small-sized, with elytral seta d1 missing, seta $\mathrm{d} 2$ situated at or just before middle, and the antennae short.

\subsection{Amphimenes (s. str.) micros Fedorenko, 2014}

Fedorenko, 2014: 309 (Chu Yang Sin NP, southern Vietnam). MATERIAL. Central Vietnam: $2 \sigma^{7} \sigma^{7}$, 9 (SIEE; D. Fedorenko leg.), Gia Lai, $50 \mathrm{~km}$ N of An Khe, Kon Chu Rang Nature Reserve, $14^{\circ} 31^{\prime} \mathrm{N} 108^{\circ} 32^{\prime} \mathrm{E}, \mathrm{h}=1000-1040 \mathrm{~m}, 24 . \mathrm{V}-2$.VI.2016; + (SIEE), Kon Tum, Kon Plong Distr., $14^{\circ} 45^{\prime} \mathrm{N} 108^{\circ} 18^{\prime} 10^{\prime \prime} \mathrm{E}$, env. ngock Boc 1 Mt., h=1300-1400 m, 8-10.VI.2016; O', Quang Nam, Nam Gian Distr., Song Thanh National Park, $15^{\circ} 32-33^{\prime} \mathrm{N} 103^{\circ} 22-23^{\prime} \mathrm{E}$, $\mathrm{h}=1100-1230 \mathrm{~m}, 23 . \mathrm{IV}-11 . \mathrm{V} .2019$.

REDESCRIPTION. Unnecessary except the following corrections: BL 4.3-5.2 mm. PW/PL 1.25-1.40 (1.37, $\mathrm{n}=6)$, PW/HW 1.34-1.47 (1.43), PB/PA 1.21-1.35 (1.26), EL/EW 1.35-1.41 (1.39), EW/PW 1.49-1.59 (1.55), D2/EL 0.39$0.46(0.42, \mathrm{n}=6 \times 2), \mathrm{D} 3 /$ EL $0.91-0.95(0.92)$.

DISTRIBUTION. This species was previously known from Dak Lak Province only. The listed records extend the species range farther northwards.
Bates H.W. 1873. On the geadephagous Coleoptera of Japan // Trans.

Bates H.W. 1892. Viaggio di Leonardo Fea in Birmania e regioni vicine. XLIV. List of the Carabidae // Ann. Mus. Stor. Nat. Genova. Vol.12. No.32. P.267-428.

Chaudoir M. 1869. Mémoire sur les Thyréoptérides // Ann. Soc. Ent. Belg. T.12. P.113-162

Fedorenko D.N. 2010. New or little-known species of the genus Amphimenes Bates, 1873 (Coleoptera, Carabidae, Lebiinae)

Fedorenko D.N. 2014. New or little-known Pericalina and Cymindidina (Coleoptera: Carabidae: Lebiini) from the Oriental region // Russ. Ent. J. Vol.23. No.4. P.305-315.

Habu A. 1964. On the species of the genus Amphimenes (Coleoptera, Carabidae) // Kontyû. Vol.32. No.4. P.472-478.

Habu A. 1967. Carabidae Truncatipenne group (Insecta, Coleoptera). Fauna Japonica. Biogeographical Society of Japan. Tokyo. xiv +338 pp. +27 pl.

Habu A. 1982. Revised and supplementary notes on and descriptions of the Truncatipennes group of Japan (II) (Coleoptera, Carabidae) // Ent. Rev. Japan. Vol.37. No.2. P.83-118.

Hunting W., Yang M.-M. 2019. A taxonomic review of the pericaline ground-beetles in Taiwan, with descriptions of new pecies (Coleoptera, Carabidae, Lebiini) // ZooKeys. Vol.816. P.1-164. doi: 10.3897/zookeys.816.29738.

Jedlička A. 1963. Monographie der Truncatipennen aus Ostasien. Lebiinae - Odacanthinae - Brachininae (Coleoptera, Carabidae) // Entomol. Abhandl. Staatl. Mus.Dresden, Dresden. Bd.28. Nr.7. S.269-579.

Kirschenhofer E. 1999. Über neue und wenig bekannte Carabiden Arten und Gattungen aus Südeuropa, Kleinasien, Süd- und Südostasien (Coleoptera: Carabidae: Lebiinae) // Ann. Hist.Nat. Mus. Nat. Hung. Vol.91. S.67-79.

Nakane T. 1957. New or little-known Coleoptera from Japan and its adjacent regions, XIV // Sci. Rep. Saikyo Univ. Vol.2(A). P.235-240. Roy. Ent. Soc. London. P.219-322. from Vietnam // ZooKeys. Vol.65. P.14-50. 